New Zealand Plant Protection Society (Inc)

\title{
Phytophthora Symposium
}

12 August 2019, Stamford Plaza, Auckland, New Zealand

\section{Abstracts}

Edited by R.E. Bradshaw and I.J. Horner

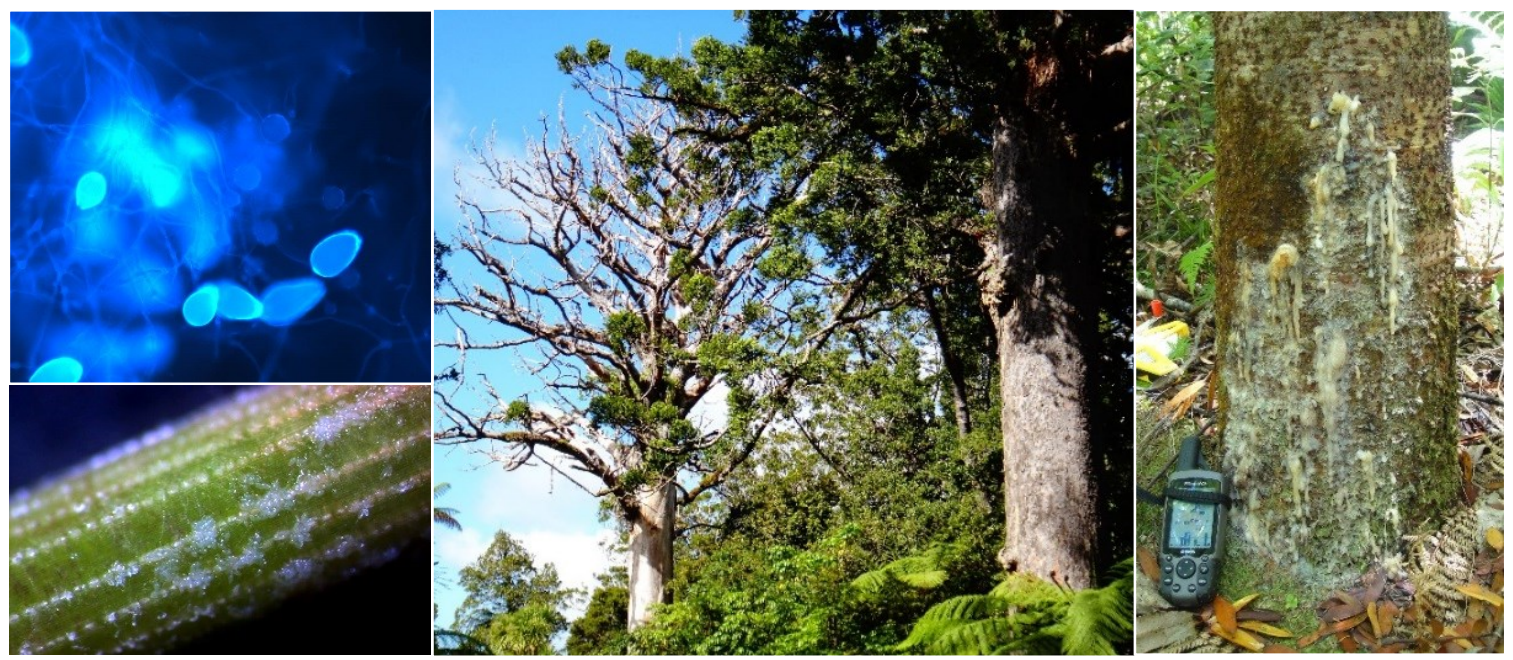

\section{AGMARDT}

FUTURE SHAPERS

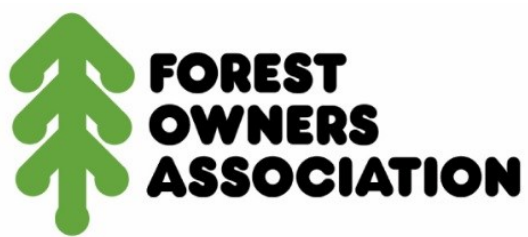

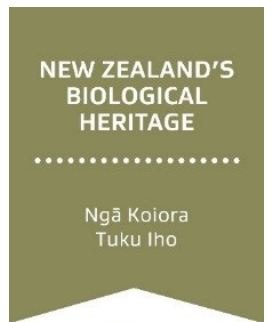

National

SCIENCE

challenges

A MINISTRY OF BUSINESS, 


\section{Cover photos}

Top left: Phytophthora pluvialis sporangia and hyphal swellings, stained with calcofluor white and viewed under fluorescent microscope (Photo: S. Hunter) Bottom left: P. pluvialis sporangia on pine needle (Photo: Nari Williams) Centre: Kauri dieback, dead and asymptomatic trees (Photo I.J. Horner) Right: Sap bleed on kauri ricker infected with P. agathidicida (Photo I.J. Horner) 


\section{Welcome to the New Zealand Plant Protection Society (NZPPS) Phytophthora Symposium}

On behalf of the NZPPS Executive committee, I would like welcome everyone to the symposium and to thank the NZPPS Phytophthora Symposium organizing committee for all of their hard work. With the increase in awareness of the importance of Phytophthora pathogens across plant systems this symposium is very timely. The Phytophthora Symposium brings together researchers from across the country actively working on Phytophthora biology and management, along with four international speakers to bring a unique global perspective to the discussion.

Eirian Jones (New Zealand Plant Protection Society President)

The NZPPS Phytophthora Symposium organizing committee would also like to welcome everyone to the symposium and to acknowledge the contributions of our major sponsors. Thanks to AGMARDT which provided a Conference Grant for Dr Niklaus Grunwald and Dr Richard Cobb to travel from the USA to present at the symposium and attend research meetings. Thanks to the Biological Heritage National Science Challenge which sponsored Dr Sarah Green and Dr Mariella Marzano from Forest Research in the United Kingdom to travel and present at the symposium. We would also like to thank our other major sponsor the New Zealand Forest Owners Association who have sponsored the evening Poster session event. Thanks also to our other sponsors the Ministry of Business, Innovation and Employment (MBIE), the Department of Conservation and New Zealand Avocado. Lastly, we would like to thank the NZPPS society for hosting the symposium.

\section{NZPPS Phytophthora Symposium Organising Committee}

Karyn Froud, Biosecurity Research

Bill Dyck, Forest Owners Association

Nari Williams, Scion

Rosie Bradshaw, Massey University

Ian Horner, Plant \& Food Research

Nick Waipara, Plant \& Food Research, Auckland University

Joy Tyson, Plant \& Food Research

Eirian Jones, Lincoln University, NZPPS President

Please reference abstracts from this symposium as:

Authors. 2019. Title of abstract. In: Bradshaw, R.E. and Horner, I.J. (Eds.) Abstract Proceedings from the New Zealand Plant Protection Society Phytophthora Symposium, 12 August 2019, Auckland, New Zealand, page numbers.

ISBN 978-0-473-49002-7

https://doi.org/10.30843/nzpps.2019.symp 



\section{CONTENTS}

SESSION 1: INTRODUCTION TO PHYTOPHTHORA: 1

Phytophthora in a global context and mitigation through understanding risk of spread in trade

Sarah Green, David Cooke, Mariella Marzano, Bethan Purse, Paul Sharp, Dan Chapman, Alexandra Schlenzig, Jane Barbrook, Tim Pettit, Ana Pérez-Sierra, Mhairi Clark, Debra Frederickson-Matika, Beatrix Clark, Eva Randall, Gregory Valatin, Mike Dunn, Leighton Pritchard, Peter Thorpe, Peter Cock, Ewan Mollison, Louise Barwell 2

Phytophthora in New Zealand - linking local plant health issues to the global context

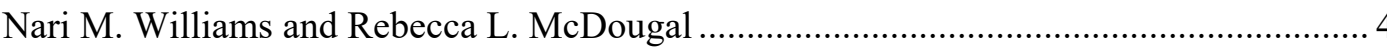

Epidemiology and management of red needle cast of pine

Stuart Fraser, Ian Hood, Carol Rolando, Lindsay Bulman, Nari Williams ........................... 5

Phytophthora and allies along a river salinity gradient

Bevan Weir, Rose Williams, Natalie Morse, Duckchul Park, David Waite, Hwee Sze

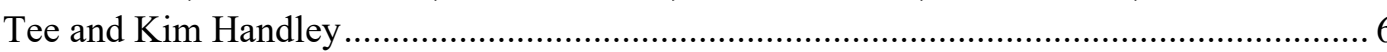

SESSION 2: INTRODUCTION TO PHYTOPHTHORA: 2

From genes to management: deploying the most appropriate technology to inform Phytophthora biology and management

Niklaus J Grünwald 8

Population genomics of Phytophthora forest pathogens

Rebecca L. McDougal, Preeti Panda, David J. Studholme, Simren Brar, Javier Tabima, Brent Kronmiller, Niklaus J. Grunwald, Jared LeBoldus, Brett M. Tyler, Rosie E.

Bradshaw, Peter Scott, Shannon Hunter, Kristi Kennedy, Eugenio Sanfuentes, Jonas

Oliva, Miguel Angel Redondo, Andrew Armitage, May Bente Brurberg, Laura

Grenville-Briggs, Ramesh Vetukuri, Nari M. Williams

Risk of Phytophthora to kiwifruit

Sonia Whiteman and Matt Dyck

Return to Paradise: The fall and rise of taro in Samoa - Taro leaf blight

Bob Fullerton, Joy Tyson, Kieran Mellow Seeseei Molimau-Samasoni, Angelika

Tugaga, Amy Maslen-Miller, Fa'alelei Tunupopo.

Kauri dieback - a brief history and a long future

Ian J Horner 15

SESSION 3: MITIGATION, RESILIENCE AND MANAGEMENT: 1.

Plants, pests and practice: bridging the gap between knowledge and action to better manage plant health

Mariella Marzano, Mike Dunn and Sarah Green.

Inclusive, adaptive management of Phytophthora agathidicida in Waipoua Forest, Aotearoa-New Zealand: An Indigenous perspective

Taoho Patuawa, Tom Donovan, Taoho Tane, Ian Horner, Peter Scott, Nick Waipara, Matthew Calder, Tony Beauchamp, Nari Williams, Stanley Bellgard, Amanda Black, Lee Hill, Paul Barber, Giles Hardy.... 
Kauri dieback surveillance - research and disease distribution

Karyn Froud, Travis Ashcroft, Chris Green, Tony Beauchamp, Kim Parker, Tui Shortland, Juliane Chetham, Welcome Ho, Yue Chin Chew, Murray Fea, Gavin Clapperton, Nick Waipara ...

Kauri dieback screening and resilience: histopathological changes associated with New Zealand kauri roots due to infection with Phytophthora agathidicida

Stan E Bellgard, Chantal M Probst, Mahajabeen Padamsee, Nari M Williams, Bevan

S Weir.

Identifying disease suppressive soil microbial communities to protect kauri against dieback disease

Alexa Byers and Amanda Black

Breeding for resistance to red needle cast (Phytophthora pluvialis)

Natalie Graham, Mari Suontama, Tony Pleasants, Yongjun Li, Martin Bader, Jaroslav Klápště, Heidi Dungey, and Nari Williams .24

SESSION 4: MITIGATION, RESILIENCE AND MANAGEMENT: 2. 26

Phosphite for control of kauri dieback

Ian J Horner, Matthew Arnet, Ellena Carroll, Mary Horner.

Foschek: foliar applications for increasing phosphonate levels in avocados

Meredith Guy, Gordon Harris, Stephen McKennie, Chris Molloy and Alan Wells. 28

Mātauranga guided biodiscovery of anti-Phytophthora compounds

Monica L. Gerth 30

Bio-Assay Guided Identification of Phytophthora agathidicida chemo-attractants and repellents

Randy Lacey, Sarah Andreassend and Monica Gerth 31

Why, what, and where; responding to relentless and disruptive invasive Phytophthora

Richard C. Cobb 32

POSTERS 33

First record of Phytophthora pini in New Zealand

K. S. J. Lewis, A. Black, L. M. Condron, N. W. Waipara, N. Williams and P. Scott 34

Identifying molecular invasion patterns from the kauri dieback pathogen, Phytophthora agathidicida

E. L. Bradley, P. Panda, R.E. Bradshaw and C. Mesarich 34

Know thy enemy: plant pathogen genomics advancing disease management

R. L. McDougal, P. Panda, S. Brar, L. Hunziker, P.-Y. Dupont, Y. Guo,

R.E. Bradshaw and N.M. Williams .35

Genomic insights into a Phytophthora hybrid isolated from New Zealand soil

W.H. Ho, L.A. Rigano, C. Pal, R. McDougal, J. Gardner, N. Ward, B.J.R. Alexander..... 35

Analysis of Host-Pathogen Interactions by Liquid Chromatography Mass Spectroscopy (LC-MS)

S. J. Hill, I. Isak, and L. G. Raymond 36 
Using NMR to study host-pathogen interactions between kauri callus tissues and Phytophthora species

L. G. Raymond, S. J. Hill and N. M. Williams 36

Characterisation of RXLR effectors from the kauri pathogen Phytophthora agathidicida

Y. Guo, P.Y. Dupont, C.H. Mesarich, P. Panda, N.M. Williams, R.L. McDougal, and

R.E. Bradshaw .

Discovery and characterisation of viral and viral-like sequences associated with the genomes of New Zealand Phytophthora species

Z. Xu, M. Khalifa, R. MacDiarmid, G. Smith, F. Kalamorz, R. Frampton, R. McDougal.

Effects of plant nutrient amendments on infection and disease of kauri (Agathis australis) caused by Phytophthora agathidicida

K. D. D’Souza, M. Bader, N. Williams, C. Probst, S. Bellgard and P. Scott 38

Inoculating Agathis australis with fungal endophytes to test the viability of a potential biological control agent for Phytophthora agathidicida

K.A. Bradford, M. Padamsee, N.M. Williams, J. Krajňáková 38

Antimicrobial resistance and sensitivity in Phytophthora agathidicida

K.J. Daley, M. L. Gerth, W.M. Patrick

Mātauranga and microbiology: a new type of education

A. Sucsy and M.L. Gerth 39

Destroying the Plant Destroyer: Biodiscovery of new anti-microbials to prevent kauri dieback

M.J. Fairhurst and M.L. Gerth 40

Foliar phosphite application controls Phytophthora cinnamomi in six ecologically significant New Zealand plant species

Peter Scott, Nari Williams, Martin Bader. 40

Kauri Rescue ${ }^{\mathrm{TM}}$ : A citizen science programme evaluating kauri dieback controls

Ian Horner, Mels Barton, Lee Hill, Linley Jesson, Ngaire Kingsbury, Marie McEntee,

Nick Waipara, Waitangi Wood

Evidence of phosphite resistance in Phytophthora species with intensive use in nurseries and horticulture

S.R. Hunter, P.M. Scott, N.M. Williams, and R.L. McDougal 


\section{SESSION 1: INTRODUCTION TO PHYTOPHTHORA: 1}

Chair: Peter Scott, Plant \& Food Research

Convener: Karyn Froud, Biosecurity Research 


\title{
Phytophthora in a global context and mitigation through understanding risk of spread in trade
}

Sarah Green ${ }^{1}$, David Cooke ${ }^{2}$, Mariella Marzano ${ }^{1}$, Bethan Purse ${ }^{3}$, Paul Sharp ${ }^{4}$, Dan Chapman ${ }^{5}$, Alexandra Schlenzig ${ }^{6}$, Jane Barbrook $^{7}$, Tim Pettit ${ }^{8}$, Ana Pérez-Sierra ${ }^{1}$, Mhairi Clark ${ }^{1}$, Debra Frederickson-Matika ${ }^{1}$, Beatrix Clark $^{2}$, Eva Randall ${ }^{2}$, Gregory Valatin ${ }^{1}$, Mike Dunn ${ }^{1}$, Leighton Pritchard $^{2}$, Peter Thorpe ${ }^{2}$, Peter Cock $^{2}$, Ewan Mollison ${ }^{4}$, Louise Barwell ${ }^{3}$

${ }^{1}$ Forest Research, Northern Research Station, Roslin, Midlothian, EH25 9SY, UK

${ }^{2}$ The James Hutton Institute, Invergowrie, Dundee, DD2 5DA, UK

${ }^{3}$ The Centre for Ecology \& Hydrology, Maclean Building, Benson Lane, Crowmarsh Gifford, Wallingford, Oxfordshire, OX10 8BB, UK

${ }^{4}$ The University of Edinburgh, Old College, South Bridge, Edinburgh EH8 9YL, UK

${ }^{5}$ The Centre for Ecology \& Hydrology, Bush Estate, Penicuik, Midlothian, EH26 0QB, UK

${ }^{6}$ Science and Advice for Scottish Agriculture, 1 Roddinglaw Rd, Edinburgh, EH12 9FJ, UK

${ }^{7}$ Animal and Plant Health Agency, Plant Health and Seeds Inspectorate, Sand Hutton, York, YO41 1LZ, UK

${ }^{8}$ University of Worcestor, Jenny Lind Building, 1013 Henwick Grove, Worcester, WR2 6AJ, UK

Corresponding author: sarah.green@ForestResearch.gov.uk

\begin{abstract}
Phytophthora is a diverse genus of filamentous oomycete plant pathogens which include some of the most notorious examples of invasive and highly destructive plant disease epidemics worldwide, for example the potato late blight pathogen $P$. infestans and the two forest pathogens, $P$. cinnamomi and $P$. ramorum. Although fungus-like, Phytophthora species are more closely related to brown algae, producing motile, free-swimming zoospores which are formed in spore sacs known as sporangia. Phytophthora species also produce thick-walled resting spores that are very resilient to degradation and able to survive in plant residues and soils over years. Currently, approximately 180 species of Phytophthora have been provisionally named worldwide, with new cryptic species being described at an increasing rate as a result of global surveys for Phytophthora in many environments.
\end{abstract}

Worldwide, the impact of Phytophthora on trees in both natural and managed ecosystems has increased greatly in recent years, due in part to the inadvertent movement of these pathogens in traded plants (Jung et al. 2016). In Britain, five new species of pathogenic Phytophthora (P. ramorum, $P$. kernoviae, $P$. lateralis, $P$. austrocedri and $P$. pseudosyringae) have been reported since 2003, all causing serious damage to trees across a range of different environments and resulting in significant economic and ecological losses. In all of these cases, imported planting material has been either confirmed or strongly implicated as the most likely route of introduction.

In 2016 an interdisciplinary project (Phyto-threats; https://www.forestresearch.gov.uk/research/globalthreats-from-phytophthora-spp/) was initiated to address the risks to UK forest and woodland ecosystems from Phytophthora, by examining the distribution and diversity of Phytophthoras in UK plant nursery systems (the focus of this presentation) and providing the evidence base for the development of a set of enhanced nursery 'best practice' accreditation criteria to mitigate risk of further Phytophthora introduction and spread. This evidence base is being augmented by a greater understanding of the emerging Phytophthora threats from both global and evolutionary perspectives. Phytophthora distribution and diversity in UK nursery systems was examined on two scales; a 'fine scale' survey involving the detailed sampling of fifteen partner nurseries over a three-year period and a 'broad scale' survey involving a larger number of nurseries and garden centres sampled systematically 
during annual statutory plant health inspections. Since plant material and water are the major transmission pathways of Phytophthora, detection in both substrates were targeted. Roots were sampled from symptomatic plants, and irrigation water, run-off from potted plants, puddles and collection ponds were sampled on-site by proven filtration methods that capture Phytophthora propagules (Scibetta $e t$ al. 2012). For each nursery and environmental sample, metadata (e.g. host diversity, propagation and trading practices, irrigation and disease management, recent planting etc) were collected for downstream analysis to inform best practice.

To try and capture the highest diversity of Phytophthora species as possible in each sample a DNA detection tool known as metabarcoding was used. This method uses sequencing technology to detect all species of a target group present within an environmental sample, including species as-yet undescribed (Scibetta et al. 2012). Thousands of DNA sequences generated from each individual sample were identified using a bioinformatics pipeline and custom curated Phytophthora database developed as part of this project. Over 4,500 nursery samples have been collected as part of this project and $\sim 50 \%$ are positive for Phytophthora. Approximately 60 Phytophthora species have been identified to date and these findings will be presented in relation to host association and nursery management practice. Our data are being used to help shape a UK-wide nursery accreditation scheme currently being developed and rolled out later this year to improve plant health awareness and biosecurity in the nursery industry and to reduce the spread of these potentially devastating plant diseases.

\section{References}

Jung, T., Orlikowski, L., Henricot, B. \& Abad-Campos, P. et al. (2016). Widespread Phytophthora infestations in European nurseries put forest, semi-natural and horticultural ecosystems at high risk of Phytophthora diseases. Forest Pathology 46, 134-163.

Scibetta S, Schena L, Chimento A, Cacciola SO, Cooke DEL. (2012) A molecular method to assess Phytophthora diversity in environmental samples. Journal of Microbiological Methods. 88, 356-368. 


\section{Phytophthora in New Zealand - linking local plant health issues to the global context}

Nari M. Williams and Rebecca L. McDougal

Forest Protection, Scion, 49 Sala Street, Rotorua, New Zealand

Corresponding author: nari.williams@scionresearch.com

Phytophthora pathogens are being increasingly recognised as key threats to native ecosystems, forests and plant production systems globally. However, our response to these pathogens requires local context to differentiate between endemic, naturalised and exotic pathogens given their impact and threat to the health of native and exotic plants. This raises numerous questions for biosecurity and management:

- What do we know about the diversity and impact of Phytophthora pathogens in New Zealand?

- What critical role have these species had in the evolution of New Zealand's unique native ecosystems?

- How do we/should we differentiate between endemic, naturalised and exotic species of Phytophthora?

- Where do Phytophthora pathogens sit within the ecosystem of natural and productive land management?

- Which Phytophthora species warrant a call to action?

- How might the threat of Phytophthora pathogens change under increased climatic and anthropogenic pressure?

The population of Phytophthora species recovered from, or detected within, several natural and productive environments will be discussed along with case studies contrasting the biology and impact of Phytophthora pathogens in New Zealand plant systems. This talk will set the scene for us to reconsider what we know about Phytophthora species in New Zealand and how we respond to them. 


\title{
Epidemiology and management of red needle cast of pine
}

\author{
Stuart Fraser, Ian Hood, Carol Rolando, Lindsay Bulman, Nari Williams
}

Forest Protection, Scion, 49 Sala Street, Rotorua, New Zealand

Corresponding author: stuart.fraser@scionresearch.com

\begin{abstract}
Red needle cast (RNC), caused by Phytophthora pluvialis, is a widespread foliar disease of pine in New Zealand. To develop cost-effective management tools for $\mathrm{RNC}$, research has focused on the identification of effective active ingredients for chemical control and improving our understanding of disease epidemiology. From a list of eleven possible chemical fungicides, a series of in vitro, in planta and field trials have demonstrated that copper fungicides have potential to control RNC. Copper is wellknown to the New Zealand forest industry, as it is already used in control programmes of dothistroma needle blight. Field monitoring in the North Island of New Zealand has shown that inoculum production, infection, and symptom development all peak between autumn and spring, indicating that an application in autumn may be optimal for control. Further analysis of data from long-term disease monitoring and forest health surveys may allow the prediction of outbreak years and the identification of high risk sites. Operational field trials with copper fungicide have demonstrated that sprays in February significantly reduced RNC severity in mature plantations of radiata pine in the central North Island. Further operational scale field studies are underway to investigate the effect of spray timing and to estimate growth losses to allow cost benefit analyses of control activities.
\end{abstract}




\title{
Phytophthora and allies along a river salinity gradient
}

Bevan Weir ${ }^{1}$, Rose Williams ${ }^{1}$, Natalie Morse ${ }^{1}$, Duckchul Park ${ }^{1}$, David Waite ${ }^{2}$, Hwee Sze Tee ${ }^{2}$ and Kim Handley $^{2}$

${ }^{1}$ Manaaki Whenua - Landcare Research, Auckland, New Zealand

${ }^{2}$ School of Biological Sciences, Auckland University, Auckland, New Zealand

Corresponding author: weirb@landcareresearch.co.nz

\begin{abstract}
Phytophthora are 'water moulds' found in wet soils and water bodies such as streams and rivers. Some rivers, as they eventually flow into the ocean, become progressively more saline as they pass through an estuarine environment. This raises the question about what happens to Phytophthora. Is Phytophthora salt tolerant and can it survive in saline water? Are there marine specific Phytophthora?

In collaborative work between the Biological Heritage National Science Challenge Project 1.2 and Genomics Aotearoa Project "Environmental Metagenomics", nine sites were sampled along a salinity gradient in the Waiwera River, north of Auckland. At each site, filtered bulk water was collected and stream baits were set for one week. The most inland sample was in fresh water (S1), and the most saline sample on the beach at the river mouth (S9). Phytophthora cultures were isolated using selective media from filter fragments and from leaf baits. Total metagenomic DNA and metabarcoding loci were sequenced from the filters and sediment, and metabarcoding loci from the leaf baits.
\end{abstract}

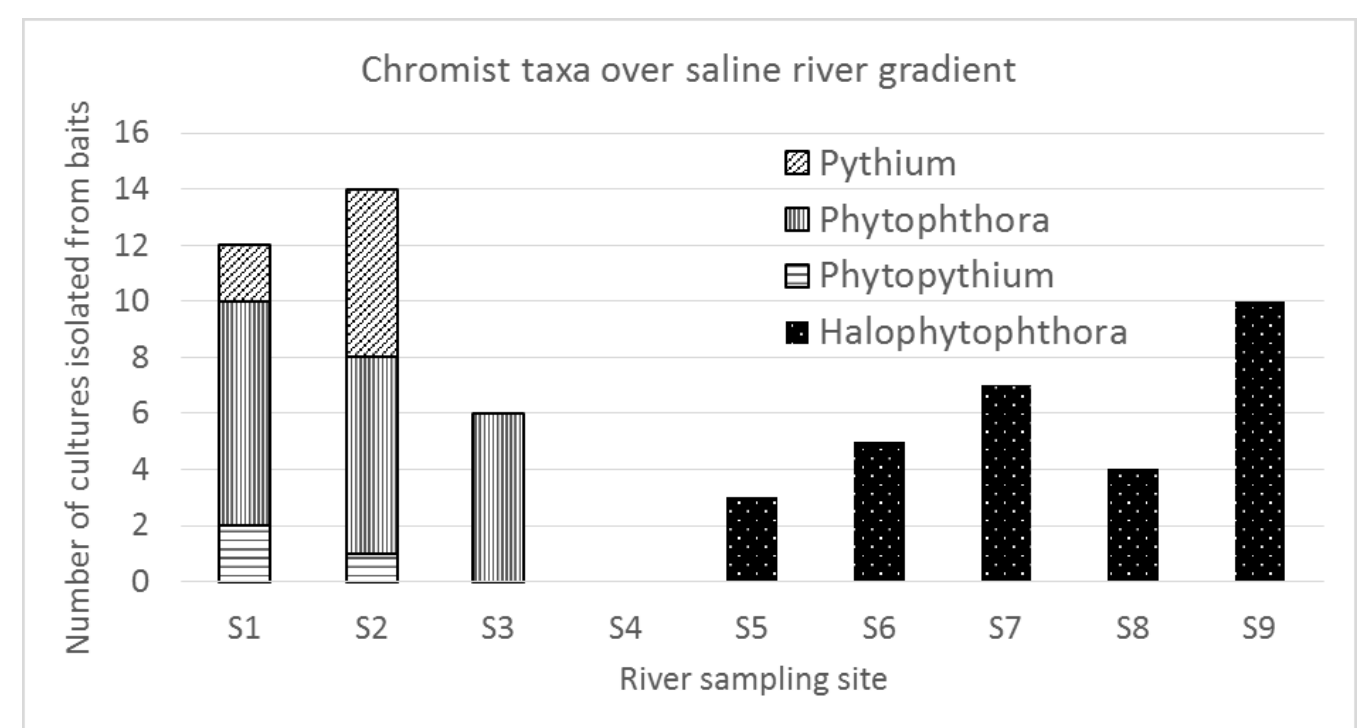

Figure 1: Stacked bar chart of chromists isolated though stream baiting at nine sites (S1-S9) along a river. S1 is freshwater, S9 is near seawater salinity. The $x$-axis indicates number of isolates recovered.

The results of the stream baiting show a striking pattern of a decline in Phytophthora, Phytopythium and Pythium species as salinity increases, and the reciprocal relationship with Halophytophthora species. Halophytophthora has not previously been confirmed as present in New Zealand. The biological implications will be discussed. 


\section{SESSION 2: INTRODUCTION TO PHYTOPHTHORA: 2}

Chair: Preeti Panda, Scion

Convener: Rosie Bradshaw, Massey University 


\title{
From genes to management: deploying the most appropriate technology to inform Phytophthora biology and management
}

\author{
Niklaus J Grünwald \\ Horticultural Crops Research Unit, USDA Agricultural Research Service, Corvallis, OR 97330 \\ Corresponding author: nik.grunwald@usda.gov
}

\begin{abstract}
Plant pathogens appear to emerge at increasing rates, be it due to a combination of climate change, increased human travel, and more frequent global trade among other factors. The genus Phytophthora harbours some of the most notorious invasive and emerging pathogens affecting forests, landscape and crop plants (1). These pathogens cause billion dollar losses annually. Notable examples include the sudden oak death pathogen $P$. ramorum and the Irish famine pathogen $P$. infestans. $P$. ramorum emerged repeatedly by at least five global migrations, three into North America and two into Europe (2). In both North America and Europe, P. ramorum populations remain clonal. Despite the fact that both mating types coexist in North America, sexual reproduction has not been observed. $P$. infestans populations show a similar pattern, but clearly undergo an apparently 'random' succession of clonal lineages as novel lineages emerge and older lineages are displaced. The South American tomato tree pathogen $P$. andina emerged via hybridization between $P$. infestans and another unknown Phytophthora species (8). This talk will provide insights into mechanisms of emergence in the genus Phytophthora using evolutionary, population genetic, bioinformatics, and genomic approaches (3-7). It is becoming increasingly clear that this genus uses an arsenal of tools and mechanisms such as effectors, hybridization, migration, and adaptation to continually re-emerge (8-11). This work provides a current assessment of Phytophthora biology with an emphasis on genomics that facilitates development of translational approaches such as targeted best management practices to manage these pathogens.
\end{abstract}

\section{References}

1. Kamoun S, Furzer O, Jones JDG, Judelson HS, Ali GS, Dalio RJD, et al. 2014. The Top 10 oomycete pathogens in molecular plant pathology. Molecular Plant Pathology 16: 413-434.

2. Grünwald NJ, Garbelotto M, Goss EM, Heungens K, Prospero S. 2012. Emergence of the sudden oak death pathogen Phytophthora ramorum. Trends in Microbiology 20: 131-138.

3. Grünwald NJ, Goss EM. 2011. Evolution and population genetics of exotic and re-emerging pathogens: Novel tools and approaches. Annual Review of Phytopathology 49: 249-267.

4. Grünwald NJ, McDonald BA, Milgroom MG. 2016. Population genomics of fungal and oomycete pathogens. Annual Review of Phytopathology 54: 323-346.

5. Knaus BJ, Grünwald NJ. 2017. VCFR: a package to manipulate and visualize variant call format data in R. Molecular Ecology Resources. 17: 44-53.

6. Kamvar ZN, Brooks JC, Grünwald NJ. 2015. Novel R tools for analysis of genome-wide population genetic data with emphasis on clonality. Frontiers in Genetics 6: 208.

7. Kamvar ZN, Tabima JF, Grünwald NJ. 2014. Poppr: an R package for genetic analysis of populations with clonal, partially clonal, and/or sexual reproduction. PeerJ 2:e281.

8. Goss EM, Cardenas ME, Myers K, Forbes GA, Fry WE, Restrepo S, et al. 2011. The plant pathogen Phytophthora andina emerged via hybridization of an unknown Phytophthora species and the Irish Potato Famine pathogen, P. infestans. PLoS ONE. 6(9): e24543.

9. Haas BJ, Kamoun S, Zody MC, Jiang RHY, Handsaker RE, Cano LM, et al. 2009. Genome sequence and analysis of the Irish potato famine pathogen Phytophthora infestans. Nature 461: 393-398.

10. Goss EM, Tabima JF, Cooke DEL, Restrepo S, Fry WE, Forbes GA, et al. 2014. The Irish potato 
famine pathogen Phytophthora infestans originated in central Mexico rather than the Andes. Proceedings of the National Academy of Science USA 111: 8791-8796.

11. Cooke DEL, Cano LM, Raffaele S, Bain RA, Cooke LR, Etherington GJ, et al. 2012. Genome analyses of an aggressive and invasive lineage of the irish potato famine pathogen. PLoS Pathogens 8(10):e1002940. 


\title{
Population genomics of Phytophthora forest pathogens
}

Rebecca L. McDougal ${ }^{1}$, Preeti Panda ${ }^{1}$, David J. Studholme ${ }^{2}$, Simren Brar ${ }^{3}$, Javier Tabima ${ }^{4}$, Brent Kronmiller $^{5}$, Niklaus J. Grunwald ${ }^{6}$, Jared LeBoldus ${ }^{4}$, Brett M. Tyler ${ }^{5}$, Rosie E. Bradshaw ${ }^{3}$, Peter Scott ${ }^{1}$, Shannon Hunter ${ }^{1}$, Kristi Kennedy ${ }^{1}$, Eugenio Sanfuentes ${ }^{7}$, Jonas Oliva ${ }^{8}$, Miguel Angel Redondo ${ }^{9}$, Andrew Armitage ${ }^{10}$, May Bente Brurberg ${ }^{11}$, Laura Grenville-Briggs ${ }^{12}$, Ramesh Vetukuri ${ }^{12}$, Nari M. Williams ${ }^{1}$

${ }^{1}$ Scion (New Zealand Forest Research Institute, Ltd.), Rotorua, New Zealand

${ }^{2}$ Biosciences, University of Exeter, Stocker Road, Exeter, EX4 4QD, United Kingdom

${ }^{3}$ School of Fundamental Sciences, Massey University, Palmerston North, NZ

${ }^{4}$ Department of Botany and Plant Pathology, Oregon State University, Corvallis, OR 97331, USA

${ }^{5}$ Center for Genome Research and Biocomputing, Oregon State University, Corvallis, Oregon, USA.

${ }^{6}$ Horticultural Crops Research Laboratory, USDA Agricultural Research Service, Corvallis, OR 97330, USA

${ }^{7}$ Laboratorio de Patología Forestal, Facultad Ciencias Forestales y Centro de Biotecnología, Universidad de Concepción, Concepción, Chile.

${ }^{8}$ Department of Vegetal Production and Forestry Science, Universitat de Lleida, Spain

${ }^{9}$ Department of Forest Mycology and Plant Pathology, Uppsala, Sweden.

${ }^{10}$ NIAB EMR, Kent, United Kingdom

${ }^{11}$ Department of Plant Sciences, Norwegian Institute of Bioeconomy Research (NIBIO), Norway

${ }^{12}$ Dept. of Plant Protection Biology, Swedish University of Agricultural Sciences, 23053 Alnarp, Sweden

Corresponding author: rebecca.mcdougal@scionresearch.com

\begin{abstract}
Phytophthora species impact exotic and native forests worldwide. In New Zealand there are multiple Phytophthora species causing disease on tree species, including Phytophthora pluvialis, the causal agent red needle cast in Pinus radiata, Phytophthora agathidicida, causing kauri dieback in Agathis australis, and Phytophthora cactorum, which has a long-standing record of disease in apple and pine. We have sequenced genomes of six Phytophthora species, using both short- and long-read sequencing platforms. Genome sequencing has improved our understanding of the populations and likely origins for some these species. For example, analysis of the SNPs present in genome sequences from Phytophthora pluvialis revealed the New Zealand strain of the pathogen likely originated from Oregon, USA ${ }^{[1]}$. In contrast, Phytophthora kernoviae, also a pathogen of pine, appears to be endemic to New Zealand based on comparative genomic analysis of isolates from Britain, New Zealand and Chile ${ }^{[2]}$. Molecular analysis of several gene regions within Phytophthora cactorum isolates have led to distinction of pine isolates, now described as a new species P. aleatoria ${ }^{[3]}$. Comparative genomic analyses are underway to further elucidate this species complex. Phytophthora taxon totara is currently being described as it is phylogenetically distinct from other Phytophthora species. It has been found infecting the foliage of totara trees in a few locations, although disease has not become widespread. Like $P$. cactorum, Phytophthora cinnamomi is a pathogen found in pine nurseries and in horticultural settings such as avocado orchards. Molecular analysis of multiple gene regions has revealed low genetic diversity of $P$. cinnamomi in New Zealand ${ }^{[4]}$, although recent research has shown variability of tolerance to phosphite ${ }^{[5,}$ ${ }^{6}$. Transcriptomic analysis of strains exposed to varying concentrations of phosphite is being used to investigate potential mechanisms of tolerance to this chemical.
\end{abstract}

Genomic analysis of these species will be discussed with respect to effector gene repertoires, in planta transcriptomic analysis and resistance screening, all of which unravel molecular host-pathogen 
interactions that will aid in genome-assisted breeding programs and inform disease management in the future.

1.Brar, S., J.F. Tabima, R.L. McDougal, et al. 2018. Genetic diversity of Phytophthora pluvialis, a pathogen of conifers, in New Zealand and the west coast of the United States of America. Plant Pathology 67: 1131-1139. DOI: doi:10.1111/ppa.12812.

2.Studholme, D.J., P. Panda, E. Sanfuentes Von Stowasser, et al. 2019. Genome sequencing of oomycete isolates from Chile supports the New Zealand origin of Phytophthora kernoviae and makes available the first Nothophytophthora sp. genome. Molecular Plant Pathology 20: 423431 DOI: doi:10.1111/mpp.12765.

3.Scott, P., P. Taylor, J. Gardner, et al. 2019. Phytophthora aleatoria sp. nov., associated with root and collar damage on Pinus radiata from nurseries and plantations. Australasian Plant Pathology, 2019 DOI: 10.1007/s13313-019-00631-5.

4.Kennedy, K. and R. McDougal, 2016. Molecular Investigation into the Diversity of Phytophthora cinnamomi in New Zealand Unpublished report. Scion: Rotorua, New Zealand.

5.Hunter, S., R. McDougal, M.J. Clearwater, et al. 2018. Development of a high throughput optical density assay to determine fungicide sensitivity of oomycetes. Journal of Microbiological Methods 154: 33-39. DOI: 10.1016/j.mimet.2018.10.006.

6.Hunter, S., N. Williams, R. McDougal, et al. 2018. Evidence for rapid adaptive evolution of tolerance to chemical treatments in Phytophthora species and its practical implications. PLoS One 13(12): e0208961 DOI: 10.1371/journal.pone.0208961. 


\title{
Risk of Phytophthora to kiwifruit
}

\author{
Sonia Whiteman ${ }^{1}$ and Matt Dyck $^{2}$ \\ ${ }^{1}$ Zespri International Limited, 400 Maunganui Rd, Mt Maunganui, New Zealand \\ ${ }^{2}$ Kiwifruit Vine Health, 25 Miro Street, Mt Maunganui, New Zealand \\ Corresponding author: Sonia.Whiteman@zespri.com
}

\begin{abstract}
Decline and death of kiwifruit vines, particularly in orchards over 20 years old, is considered part of 'business as usual' for kiwifruit growers. The causal agents are seldom properly identified and both Armillaria and Phytophthora have been mentioned in passing as potential 'guilty suspects'. However, in recent years concern increased regarding the potentially significant biosecurity threat that Phytophthora represents to kiwifruit. The significant impact of Phytophthora agathidicida on our native kauri and the mysterious Italian 'Verona Vine Decline'/'Moria disease' that has had serious impacts in kiwifruit orchards has brought Phytophthora very much into focus for our kiwifruit biosecurity agents. With this threat in mind Zespri, Kiwifruit Vine Health $(\mathrm{KVH})$ and Biosecurity New Zealand under the Government Industry Agreement commissioned a literature review of the threat of Phytophthora to kiwifruit and key findings are presented. Further, through Zespri's relationships with growers and researchers in Italy some insights are provided on Verona Vine Decline/Moria disease.
\end{abstract}

The commissioned literature review was completed by Professor Steve Woodward and Dr Eric Boa of the University of Aberdeen. This literature review is freely available by contacting Sonia Whiteman. The main findings were that:

- Typical Phytophthora infections of kiwifruit result in root and collar rot, reductions in fruit yields and sometimes plant death.

- Thirty Phytophthora species are known to be present in New Zealand.

- The most important Phytophthora species affecting kiwifruit, based on frequency of reports, are P. cactorum, P. cinnamomi, P. citrophthora, P. cryptogea and P. megasperma, all of which are present in New Zealand.

- Of the species present in New Zealand and not previously reported on kiwifruit the following species are considered a risk of host jumping to kiwifruit based on their current woody hosts: $P$. agathidicida, $P$. x cambivora, $P$. captiosa, $P$. fallax, $P$. kernoviae, $P$. medicaginis, $P$. multivora, $P$. plurivora and $P$. syringae.

- Species recorded from kiwifruit but not currently present in New Zealand, so key biosecurity incursion threats, are: $P$. cactorum sensu stricto, $P$. cryptogea, $P$. drechsleri, $P$. lateralis and $P$. palmivora.

- Biosecurity New Zealand has some of the most stringent regulations for the prevention of introduction of invasive alien pests and pathogens. However, the arrival of Pseudomonas syringae pathovar actinidiae in New Zealand, indicates that in spite of best efforts at the borders, incursions still occur.

- The temperature and rainfall associated with New Zealand's oceanic climate means most the country, apart from at the highest elevations, is highly suitable for Phytophthora species to establish and cause damage on host plants. Climate change is likely to increase this suitability.

- Based on case studies of three long-known damaging problems caused by Phytophthora the following managed tools were highlighted:

- Cultural control - establish good drainage. Phytophthora species are 'water moulds', requiring high soil or atmospheric moisture to grow, reproduce and cause disease. 
- Chemical control - the application of chemicals based on phosphonate. On woody plants, the chemicals can be applied by trunk injections, although this procedure is damaging to the plant and cannot be repeated regularly.

- Cultivars - breeding host plants with resistance to Phytophthora. In woody crop plants such as apple and avocado, work has focused on the resistance status of the rootstocks onto which the scions are grafted, and several clonal lines are available for field deployment.

In 2012, decline and death of kiwifruit vines was reported in Northern Italy, near the town of Verona. The syndrome was initially name 'Verona vine decline', a name that was changed to La Moria or 'the death' as it was found to the west is Turin and the east Udine. There has been considerable debate about the cause of this syndrome. Outcomes of a recent Masters thesis by Edoardo Caldera (Department of Agricultural and Food Sciences, University of Bologna) (shared as a personal communication by Francesco Spinelli and Irene Donati) include:

- A recommendation of a name change to Kiwifruit Vine Decline Syndrome (KVDS)

- An observation that KVDS is more frequently associated with water logged and/or poorly aerated soil

- The populations of known plant pathogens of vines both with and without KVDS was investigated. Phytophthora megasperma, Phytophthora infestans and Phytopythium sp. were found in both symptomatic and non-symptomatic vines. Armillaria tabescens was only found in symptomatic vines. All of these pathogens induced KVDS symptoms when inoculated into potted vines. Whilst the amount of irrigation didn't impact symptom expression, the incidence of re-isolation of fungi was found to be higher at higher irrigation levels.

- The authors concluded that KVDS is a complex interaction of a fungal pathogen, possibly a consortium, with abiotic factors such as soil moisture content that requires further investigation. Of note is a general observation by Zespri staff that not only is flood irrigation a common practice but where sprinkler irrigation is used there is a tendency for growers to over-irrigate. Research is currently underway to optimise irrigation application for Italian conditions.

Zespri/KVH are hoping to commission survey work to build on existing knowledge of the biodiversity of Phytophthora species on New Zealand kiwifruit plants with an objective of allowing the kiwifruit industry to:

a) better assess the effects of Phytophthora on current kiwifruit production;

b) determine if future detections represent new-to-New Zealand Phytophthora and thus pose threats to trade or kiwifruit bio-protection.

$\mathrm{KVH}$ in partnership with Biosecurity New Zealand are also well advanced in developing a readiness plan for deployment should a Phytophthora incursion occur. 


\title{
Return to Paradise: The fall and rise of taro in Samoa - Taro leaf blight
}

\author{
Bob Fullerton ${ }^{1}$, Joy Tyson ${ }^{1}$, Kieran Mellow ${ }^{1}$ Seeseei Molimau-Samasoni ${ }^{2}$, Angelika Tugaga ${ }^{2}$, Amy \\ Maslen-Miller', Fa'alelei Tunupopo ${ }^{3}$ \\ ${ }^{1}$ Plant and Food Research, Auckland \\ ${ }^{2}$ Pathology and Postharvest Technologies Division, Scientific Research Organisation of Samoa \\ ${ }^{3}$ Crops Division, Samoa Ministry of Agriculture and Fisheries
}

Corresponding author: bob.fullerton@plantandfood.co.nz

\begin{abstract}
Taro leaf blight (TLB), caused by Phytophthora colocasiae (Pc), is one of the most destructive diseases of taro, Colocasia esculenta. Endemic to South East Asia, the putative centre of origin the pathogen, Pc was recorded in Hawai'i in 1920, and then in Papua New Guinea (PNG) and the Solomon Islands during the 1940s. Its distribution in the Pacific remained restricted to those countries until 1993 when it when it was introduced to Samoa, possibly from Hawai'i via American Samoa.
\end{abstract}

The Samoan incursion was a classical and catastrophic 'pathogen re-encounter' event. Taro had been selected and vegetatively propagated as a staple food in Polynesia for centuries in the absence of leaf blight. All varieties were susceptible. With the incursion, all Samoan crops were destroyed within 6 months, the lucrative export trade ceased, and the rural population faced financial hardship and food shortages. Farmers planted the more resistant but inferior ta'amu (giant taro; Alocasia macrorrhiza) to maintain food supplies. Chemical control was effective but unaffordable for most households.

Three regional research programmes were initiated to develop blight resistant varieties:

1. The Taro Genetic Resources and Utilisation Project (TAROGEN: AUSAID/SPC/NZ AID) comprised resistance breeding in PNG and Samoa, germplasm characterisation, and the establishment of a Regional Germplasm Centre at the Secretariat for the Pacific Community (SPC)., Suva

2. The Taro Network for South-east Asia and Oceania (TANSAO: EU) assembled a core sample of genotypes capturing most of the genetic diversity in SE Asia.

3. The Samoa Taro Improvement Project (TIP: University of the South Pacific) implemented a recurrent mass selection breeding programme using a farmer participatory evaluation and selection process.

Plant and Food Research (as HortResearch) contributed to both the PNG and Samoa breeding programmes by developing methods for rapid resistance screening of taro genotypes. By the mid-2000s the Samoan TIP had delivered a number of varieties with high tolerance to disease and acceptable eating qualities. Industry recovery was rapid and by 2014-15 there was oversupply in the New Zealand export market and access for fresh exports to Australia was sought. However, fresh taro corms are a prohibited import to Australia from any country with TLB.

Taro leaf blight is normally characterised by leaf lesions. However, there are isolated reports of $P$. colocasiae causing a corm rot, although this symptom has not been recorded in Samoa. Work has been underway to define the biotic constraints to fresh taro from Samoa gaining market access to Australia. This included identifying whether corms of the new Samoan TLB-tolerant cultivars could be infected, defining the conditions in which corm infection can occur, exploring the potential for pre-harvest infection, and determining the effect of storage conditions on the survival of Pc in corms. In case of the need for a disinfection treatment to eliminate viable Pc from corms, a research programme based on heat treatment is being developed. 


\title{
Kauri dieback - a brief history and a long future
}

\author{
Ian J Horner
}

Plant \& Food Research, Private Bag 1401, Havelock North 4157, New Zealand

Corresponding author: ian.horner@plantandfood.co.nz

\begin{abstract}
Kauri dieback, caused by Phytophthora agathidicida, is decimating kauri (Agathis australis) forests in northern Aotearoa-New Zealand, indiscriminately killing kauri trees of all ages, from seedlings to giant taonga (treasure) trees. Kauri is a keystone species, an ecosystem engineer that determines what other species of plant, animal and microbe inhabit the forest. So loss of kauri will, in the long term, have a major impact on whole forest composition. First recorded on Great Barrier Island in the 1970's (Gadgil, 1974), the pathogen and the disease it causes remained largely unnoticed until the mid-2000s, when it was 'rediscovered' in the Waitakere ranges causing substantial losses of kauri ricker trees (Beever et al. 2009, Weir et al. 2015). Since then, P. agathidicida has been found throughout much of kauri's natural range, in forests including Waipoua, Raetea, Warawara, and Whangaroa in Northland, in forest remnants throughout the Kaipara region and in the Coromandel.
\end{abstract}

It is difficult to determine the actual distribution of kauri dieback because of the very long latency phase from root infection to above-ground symptom expression. In large trees the latency phase could be decades. Trees that are currently showing symptoms, and thus targeted for testing, were probably infected many years ago. Due to the latency of disease expression it is likely that many currently asymptomatic trees (and forests) are already infected with the pathogen. Improved detection techniques might help delineate the pathogen, but detection will still be limited by the field sampling process.

The incidence and behaviour of $P$. agathidicida suggests that it is a relatively recent arrival in New Zealand, probably arriving sometime in the $20^{\text {th }}$ century, although the possibility of earlier introduction sometime in the last millennium cannot be ruled out. There is currently no published evidence that the organism is native.

Now that $P$. agathidicida is established and widely distributed in forests, it is here to stay, and will continue to have a huge impact on our forests for a long time to come. Long-term preservation of kauri ecosystems relies on finding ways of preventing its spread into currently 'clean' forests, and minimising its impact where it is already present. This poses a challenge to land managers, kaitiaki (guardians), communities and to scientists to come up with creative, effective and practical ways to exclude, contain or control this pathogen. Over the past 13 years there has been a substantial increase in the amount of interest and of research on Phytophthora in New Zealand, much of it related to kauri dieback.

Despite this research, there are still many unknowns about the basic biology of P. agathidicida, and some of these things have huge implications for management. Little is known about the host range; to date, kauri is the only known host killed by P. agathidicida, but it is highly likely that the pathogen has a wide range of plants that it can colonise and grow in. Such alternative hosts could have important roles in proliferation and spread of the pathogen. Relatedly, current management is based on an assumption that $P$. agathidicida is present only in kauri forests. But it is likely that it is already in forests other than kauri, perhaps existing unnoticed on alternative, possibly asymptomatic hosts.

Other gaps in our knowledge of kauri dieback include the natural rate of local pathogen spread, local vectors of the pathogen, the length of the latency period, the influence of environmental and biotic 
factors on infection and disease expression, the potential for 'resilience' in kauri forests and the role of disturbance in disease expression. Knowledge of these factors will influence and help refine management decisions.

Regarding potential controls or treatments, there are few proven options, with phosphite having the most supporting evidence to date (Horner et al 2013). But there is a dedicated effort to find alternative treatments, including those based on mātauranga Māori, natural plant extracts and alternative chemicals (e.g. Lawrence et al. 2017, 2019), seeking new treatments that might be antagonistic to the pathogen. There is a hope that in the future there might be a suite of treatments or practices that will tip the balance away from the pathogen and towards kauri tree health. These treatments will hopefully be supplemented by access to disease-tolerant kauri germplasm from dedicated screening programmes (Bellgard et al in prep), complemented by natural selection under the huge selection pressure in the forest.

The future of kauri ecosystems hangs in the balance. No single factor or piece of research will guarantee their persistence. It will require a long-term concerted effort from agencies, kaitiaki, communities, funders and importantly scientists from a number of disciplines, to come up with innovative research leading to practical solutions and management options, based on sound science.

Beever RE, Waipara NW, Ramsfield TD, Dick MA, Horner IJ 2009. Kauri (Agathis australis) under threat from Phytophthora. Phytophthoras in Forests and Natural Ecosystems 74: 74-85.

Bellgard, SE, Scott, PM, Herewini, E, Probst C, Williams, NM. Screening New Zealand Kauri (Agathis australis) for tolerance to Phytophthora agathidicida (In Prep).

Gadgil PD 1974. Phytophthora heveae, a pathogen of kauri. New Zealand Journal of Forestry Science 4: 59-63.

Horner IJ, Hough EG and Horner MB 2015. Forest efficacy trials on phosphite for control of kauri dieback. New Zealand Plant Protection 68: 7-12.

Lawrence, S.A, Burgess, E.J., Pairama, C., Black, A., Patrick, W.M., Mitchell, I., Perry, N.B., Gerth, M.L. (2019) Mătauranga-guided screening of New Zealand native plants reveals flavonoids from kānuka (Kunzea robusta) with anti-Phytophthora activity. Journal of the Royal Society of New Zealand. doi: 10.1080/03036758.2019.1648303

Lawrence, S.A., Armstrong, C.B., Patrick, W.M. and Gerth, M.L. (2017). High-throughput chemical screening identifies compounds that inhibit different stages of the Phytophthora agathidicida and Phytophthora cinnamomi life cycles. Frontiers in Microbiology 8, 1340.

Weir BS, Paderas EP, Anand N, Uchida JY, Pennycook SR, Bellgard SE and Beever RE. (2015). A taxonomic revision of Phytophthora Clade 5 including two new species, Phytophthora agathidicida and P. cocois. Phytotaxa 205: 21-38. 


\section{SESSION 3: MITIGATION, RESILIENCE AND}

MANAGEMENT: 1

Chair: Amanda Black, Te Tira Whakamātaki

Convener: Bill Dyck, Forest Owners Association 


\title{
Plants, pests and practice: bridging the gap between knowledge and action to better manage plant health
}

\author{
Mariella Marzano, Mike Dunn and Sarah Green \\ Forest Research, Northern Research Station, Roslin, Scotland, EH25 9SY \\ Corresponding author: mariella.marzano@ForestResearch.gov.uk
}

It is widely acknowledged that a major threat to tree health biosecurity comes from trade, particularly through the importation of live plants, containers and growing media. A whole range of groups from growers to consumers have been identified as instrumental in the accidental movement of pests and diseases along these pathways. Scientific knowledge can promote better plant health across relevant sectors by demonstrating the value of improved biosecurity standards and incorporating these standards into (for example) an accreditation scheme. However, the success of such a scheme would depend not only on its uptake by growers but also support from government, public consumers, retailers, the landscaping sector as well as other public and private bodies. To date the sensitivity of industry to consumer opinion and the potential for a partnership approach between these sectors has been under researched. Social science involvement in forest health is growing in the UK, providing important contributions to understanding the stakeholder landscape, knowledge and awareness of pest and diseases, and links to risky behaviours. This presentation draws on social research carried out in the UK which focussed on biosecurity attitudes and practices across the nursery, landscape and retail sectors. Here we draw mainly on research from the Phyto-threats project ${ }^{1}$ where we explored the knowledge and practices amongst key groups with direct or indirect involvement in the plant trade. Firstly, we assess the biosecurity practices and the appetite for accreditation amongst UK nurseries. Secondly, we begin to consider which factors influence the purchasing habits of landscapers, gardeners and retailers and where there is scope to influence behaviours. As part of this inquiry we provide findings from several UK-wide attitude surveys designed to better understand plant buying habits and perceptions around accreditation. We end with a brief overview of current social research on plant pests and diseases and its relevance to promoting plant health for the future.

${ }^{1}$ https://www.forestresearch.gov.uk/research/global-threats-from-phytophthora-spp/ 


\title{
Inclusive, adaptive management of Phytophthora agathidicida in Waipoua Forest, Aotearoa-New Zealand: An Indigenous perspective
}

Taoho Patuawa ${ }^{1}$, Tom Donovan ${ }^{1}$, Taoho Tane ${ }^{1}$, Ian Horner ${ }^{2}$, Peter Scott ${ }^{2}$, Nick Waipara ${ }^{2}$, Matthew Calder $^{3}$, Tony Beauchamp ${ }^{3}$, Nari Williams ${ }^{4}$, Stanley Bellgard ${ }^{5}$, Amanda Black ${ }^{6}$, Lee Hill ${ }^{7}$, Paul Barber ${ }^{8}$, Giles Hardy ${ }^{8}$

1 Te Roroa Centre of Excellence, 1 Waipoua River Road RD 6 Dargaville 0376

2 Plant and Food Research, 120 Mt Albert Road, Sandringham, Auckland 1025

3 Department of Conservation, 150 Colville Road, Dargaville 0377

4 Scion Research, Te Papa Tipu Innovation Park, 49 Sala Street, Rotorua 3010

5 Manaaki Whenua Landcare Research, 231 Morrin Road St Johns Auckland 1072

6 Lincoln University, Ellesmere Jct Rd, Lincoln 7647

7 Biosense Ltd., 128 Symonds Street, Eden Terrace, Auckland 1010

8 ArborCarbon Pty Ltd, 1 City Farm Place, East Perth WA 6004

Corresponding author:tpatuawa@teroroa.iwi.nz

\begin{abstract}
This paper presents the case study of Te Roroa in providing a management response to kauri dieback disease directly threatening the Waipoua Forest in Northland, New Zealand. Phytophthora agathidicida is the pathogen recognised to cause dieback in Agathis australis, the kauri tree of Aotearoa-New Zealand. First isolated and recognised as the likely causal agent of kauri dieback in 2006 [1], but later described in 2015 [2], researchers have since been building knowledge of the biology, ecology and dispersal mechanisms of $P$. agathidicida while also trying to address the ever-growing needs of forest managers in their efforts to make informed decisions to preserve kauri forests. An inclusive and adaptive approach initiated in 2018 by Te Roroa, the ancestral people of Waipoua Forest, is showcasing kauri dieback forest management informed by scientific knowledge, contemporary technology and Mātauranga Māori (indigenous knowledge system). Waipoua Forest covers over 13,000 hectares of varying ecological assemblages within which the keystone species and main landscape attraction is the ancient kauri tree. Once widely distributed throughout northern New Zealand, kauri were extensively logged by European settlers to the point where an estimated $2 \%$ of the original forested area remains [3]. Kauri are taonga tuku iho (enduring treasures) to Māori, however until recently, Māori have largely been removed from active participation in management. The role of Te Roroa Rangatiratanga (chiefly status) in leadership and embracing positive collaborations between the scientific community, legislative agencies and local communities will be discussed.
\end{abstract}

\section{References}

[1] Waipara NW, Hill S, Hill LMW, Hough EG, Horner, IJ. (2013). Surveillance methods to determine tree health, distribution of kauri dieback disease and associated pathogens. New Zealand Plant Protection 66: 235-241.

[2] Weir BS, Paderas EP, Anand N, Uchida JY, Pennycook SR, Bellgard SE and Beever RE. (2015). A taxonomic revision of Phytophthora Clade 5 including two new species, Phytophthora agathidicida and P. cocois. Phytotaxa 205(1): 21-38.

[3] Steward GA and Beveridge AE (2010). A review of New Zealand kauri (Agathis australis (D. Don) Lindl.): its ecology, history, growth and potential for management for timber. New Zealand Journal of Forestry Science 40: 33-59. 


\title{
Kauri dieback surveillance - research and disease distribution
}

Karyn Froud, Travis Ashcroft, Chris Green, Tony Beauchamp, Kim Parker, Tui Shortland, Juliane Chetham, Welcome Ho, Yue Chin Chew, Murray Fea, Gavin Clapperton, Nick Waipara

Kauri Dieback Programme, Planning and Intelligence Team, c/- Ministry for Primary Industries, Ruakura Research Centre, Hamilton, New Zealand

Corresponding author: travis.ashcroft@mpi.govt.nz

\begin{abstract}
The delivery of a long-term disease management programme is a complex and difficult task, particularly when the disease is widespread, cryptic, has extended latency periods and is within the native estate. The Kauri Dieback Programme (KDP) was initiated in 2009, when it became clear that what is now known as Phytophthora agathidicida was causing significant disease across multiple sites. The KDP is a joint agency response involving the Tangata Whenua Roopu (TWR; a representative body for hāpu/iwi with an interest in kauri lands), Biosecurity New Zealand (as part of the Ministry for Primary Industries), the Department of Conservation, Auckland Council, and the Northland, Bay of Plenty and Waikato Regional Councils. This abstract describes the development of a kauri dieback long-term surveillance programme.
\end{abstract}

A key goal of the KDP is to improve our understanding of the disease distribution. The KDP invested in research to operationalise detection of the pathogen $P$. agathidicida, kauri dieback disease and the host population. Pathogen detection was focused in soil, from lesions and in water. Host and disease detection were investigated via aerial, remote, and ground surveys.

Gadgil (1974) and Beever et al. (2009) both showed that P. agathidicida could be isolated from soil and lesions. Research into methods for large scale surveillance focused on soil sampling, which was optimised to an 8-point protocol, where samples are taken from four points close to the trunk and four points further towards the dripline of the tree (Dick \& Bellgard 2012). Soil baiting, while optimised, remained inconsistent between diagnostic laboratories during the early years of surveillance and significant effort into improved methodologies and detection probabilities was undertaken (Beauchamp 2012; Beauchamp \& Waipara 2014). Research into developing DNA-based soil diagnostics proved promising but did not provide added confidence over the existing methods. Detection of $P$. agathidicida in water at the catchment level was unsuccessful (Randall 2011). There is potential for increased use of lesion tissue sampling and lateral flow devices (Waipara et al. 2013). Other potential options for further research include the use of detector dogs, metabolite profiling and other molecular diagnostic tools.

The symptoms of kauri dieback (bleeding lesions on the basal trunk or roots, canopy thinning, yellowing foliage and tree death (Beever et al. 2009)) may be caused by other biotic or abiotic agents, but experienced observers improve detection likelihood (Waipara et al. 2013). In 2011 aerial surveillance commenced and has been optimised over time (Jamieson et al. 2014; Macdonald 2016), using a combination of canopy symptoms to detect suspected kauri dieback, followed by ground truthing if the site meets priority criteria, using visual observations of canopy and basal trunk lesions and soil sampling if required. Priority criteria include disease history, symptomology and forward vector risk of the site (Beauchamp 2015). Ground-truth soil sampling either adheres to the 8-point method with samples sent to two laboratories or to a sub-set of 4 soil samples close to the trunk sent to one laboratory.

Research into wide-scale kauri and disease detection has found that wide-area oblique aerial photography provides excellent identification of the baseline host population at risk and accurate 
assessment of kauri crown health (Macdonald 2016). Investment in remote sensing for stress detection of kauri, using satellite, LiDAR, multispectral and hyperspectral imagery also shows promise and is in the pre-implementation phase (Meiforth 2019).

An increased focus is on research in building knowledge and tools to identify areas of disease freedom and to undertake long-term monitoring of spread and impacts. This includes understanding test performance, designing baseline monitoring, and developing an agreed case definition for all agencies and researchers to use (Stevenson \& Froud 2019). Mātauranga Māori is a central focus to add value to surveillance in the future, building on work led by the TWR to establish a Kauri Cultural Health Monitoring Framework (Chetham \& Shortland 2013) currently being piloted amongst mana whenua communities in kauri lands.

\section{References}

Beauchamp AJ 2012. Preliminary assessment of the relationships between symptomology and detection probability of the targeted sampling of Waipoua forest for Phytophthora Taxon Agathis. Report prepared for Ministry for Agriculture \& Forestry on behalf of Kauri Dieback Joint Agency: Pp. 11.

Beauchamp AJ 2015. Ground truthing prioritisation decision tree. Report prepared for the Kauri Dieback Programme: Pp. 4.

Beauchamp AJ, Waipara N 2014. Surveillance and management of kauri dieback in New Zealand. Proceedings of the 7th Meeting of the International Union of Forest Research Organizations (IUFRO), Working Party S07-02 9: 142.

Beever RE, Waipara NW, Ramsfield TD, Dick MA, Horner IJ 2009. Kauri (Agathis australis) under threat from Phytophthora. Phytophthoras in Forests and Natural Ecosystems 74: 74-85.

Chetham J, Shortland T 2013. Kauri Cultural Health Indicators - Monitoring framework. Report prepared for the Kauri Dieback Programme.

Dick M, Bellgard SE 2012. Soil Survey method for Phytophthora taxon Agathis. Report prepared for Ministry for Agriculture \& Forestry on behalf of Kauri Dieback Joint Agency Version 2.1, modified by T. Beauchamp, DoC.: Pp. 13.

Gadgil PD 1974. Phytophthora heveae, a pathogen of kauri. New Zealand Journal of Forestry Science 4: 59-63.

Jamieson A, Bassett I, Hill L, Hill S, Davis A, Waipara N, Hough E, Horner I 2014. Aerial surveillance to detect kauri dieback in New Zealand. New Zealand Plant Protection 67: 60-65.

Macdonald A 2016. Surveillance methodology for Kauri dieback surveillance 2016/17 A methodology report prepared for the Kauri Dieback Programme by Biospatial Limited: Pp. 11.

Meiforth JJ 2019. Remote sensing of kauri dieback disease. Research project between the University of Canterbury and the Ministry for Primary Industries (on behalf of the Kauri Dieback Programme): Pp. 8.

Randall SD 2011. Fishing for Phytophthora: A Year-long Investigation Into the Diversity of Phytophthora Species in the Waitakere Ranges, Auckland, NZ. thesis, University of Auckland. p.

Stevenson M, Froud K 2019. Design of a Baseline Monitoring Methodology for Kauri Dieback. Report of a stakeholder workshop held at the Ministry for Primary Industries on 29 May 2019.

Waipara N, Hill S, Hill L, Hough E, Horner I 2013. Surveillance methods to determine tree health, distribution of kauri dieback disease and associated pathogens. New Zealand Plant Protection 66: 235-241. 


\title{
Kauri dieback screening and resilience: histopathological changes associated with New Zealand kauri roots due to infection with Phytophthora agathidicida
}

\author{
Stan E Bellgard ${ }^{1}$, Chantal M Probst ${ }^{1}$, Mahajabeen Padamsee ${ }^{1}$, Nari M Williams ${ }^{2}$, Bevan S Weir ${ }^{1}$ \\ ${ }^{1}$ Manaaki Whenua-Landcare Research, Auckland, New Zealand 1072 \\ ${ }^{2}$ Scion, NZ Forest Research, Rotorua, New Zealand, 3010 \\ Corresponding author: weirB@landcareresearch.co.nz
}

\begin{abstract}
Phytophthora agathidicida (PA) causes a root rot and collar rot of New Zealand kauri (Agathis australis). This paper describes techniques to visualize early infection of kauri by PA in deliberately inoculated seedlings. Conventional light microscopy was carried out on cleared and stained roots using trypan blue to observe PA structures. Additionally, scanning electron microscopy (SEM) was used to study the PA root structures at a higher resolution. A fluorescent in situ hybridization assay (FISH) was developed using a PA-specific probe to label PA structures in planta. Infection progression in roots of 2-year-old kauri inoculated with PA at 5, 10, 16 and 20 days post-inoculation (d.p.i.) was compared using these three approaches. Light microscopy identified no Phytophthora-like structures in the control treatments. In PA-inoculated plants, lignitubers were produced 5 d.p.i. in cortical cells. Infection was localised after 5 days, but as the infection progressed (up to 20 d.p.i.), the 'degree' of root infection increased, as did the number of replicates in which structures were observed. While SEM provided higher resolution images than the slide-based FISH-specificity assay, FISH successfully hybridized with PA hyphae, using 330-380 nm excitation and an emission filter at $420 \mathrm{~nm}$ (stained with DAPI, 4',6diamidino-2-phenylindole). Cross-reactivity was not observed when the assay was applied to cultures of six other non-target, Phytophthora species. Successful PA-specific-hybridization reactions can be applied to the analysis of field-collected root-material; aiming to differentiate spatial partitioning of pathogen with other endophytes e.g. mycorrhizal fungi.
\end{abstract}




\title{
Identifying disease suppressive soil microbial communities to protect kauri against dieback disease
}

\author{
Alexa Byers and Amanda Black \\ Bio Protection Research Centre, Lincoln University, Lincoln, Canterbury 7672 \\ Corresponding author: alexa.byers@lincolnuni.ac.nz
}

\begin{abstract}
New Zealand kauri (Agathis australis) is a coniferous tree species of the ancient family Araucariaceae. They are long lived, reaching over 2000 years old, thus making them an integral foundation ecosystem species across Northern New Zealand.

At present, only $0.75 \%$ of primary kauri forest remains due to heavy deforestation from forestry and agricultural industries. Now these forest fragments and trees are under a new threat from an introduced root pathogen Phytophthora agathidicida and are classed as threatened. This pathogen is distributed across the entire kauri range. With no known cure or deterrent, research is urgently needed for the protection of the remaining kauri forest ecosystems.
\end{abstract}

Previous research has focused on understanding the pathology of $P$. agathidicida. However, little is understood about the environmental soil factors influencing pathogen virulence and host disease expression. Our aim is to identify potential disease suppressive properties in the rhizosphere of old growth forest soils containing asymptomatic trees. The first objective of this project focuses on studying the effects of pathogen invasion on the soil microbial communities of kauri forests, in particular how it varies between diseased and healthy trees.

Using high throughput $16 \mathrm{~S}$ and ITS ribosomal RNA sequencing, we have identified differences in the composition of microbial communities from healthy and diseased kauri soils. Additionally, we have compared the microbial communities between kauri and pine soils, to understand how land fragmentation is altering the biotic soil diversity across kauri forests.

Our results show that several fungal and bacterial taxa, such as Trichoderma, Penicillium and Pseudomonas, were positively associated with healthy kauri soils. We are now screening these against $P$. agathidicida to assess their biocontrol potential. Additionally, pathogen-seedling bioassays will be conducted and preliminary results discussed regarding how soil microbial communities around the kauri root zone respond to pathogen exposure and seedling disease expression. 


\title{
Breeding for resistance to red needle cast (Phytophthora pluvialis)
}

\author{
Natalie Graham ${ }^{1}$, Mari Suontama ${ }^{1,2}$, Tony Pleasants ${ }^{3}$, Yongjun Li $^{1,4}$, Martin Bader ${ }^{1,5}$, Jaroslav Klápště ${ }^{1}$, \\ Heidi Dungey ${ }^{1}$, and Nari Williams ${ }^{1}$ \\ ${ }^{1}$ Scion, 49 Sala Street, Rotorua, New Zealand \\ ${ }^{2}$ Tree Breeding, Skogforsk, Box 3, SE-918 21 Sävar, Sweden \\ ${ }^{3} A L$ Rae Centre for Genetics and Breeding, Massey University, New Zealand \\ ${ }^{4}$ AgriBio Centre, Agriculture Victoria, 5 Ring Road, Bundoora, VIC 3083, Australia \\ ${ }^{5}$ Auckland University of Technology, 55 Wellesley St E, Auckland, New Zealand
}

Corresponding author: natalie.graham@scionresearch.com

\begin{abstract}
Phytophthora species have been recognised as foliar pathogens of radiata pine (Pinus radiata D. Don) within New Zealand (e.g., P. kernoviae (Brasier et al. 2005) and P. pluvialis (Reeser et al. 2013)) and internationally (e.g., P. pinifolia (Durán et al. 2008)). P. pluvialis has been shown to be the primary cause of red needle cast (RNC) (Dick et al. 2014), with infected needles developing olive lesions with resinous black bands, turning red and prematurely casting.

Foliar diseases have the potential to negatively affect growth and productivity (Ganley et al. 2014). The development of disease resistant/tolerant cultivars has therefore been a priority for pine breeding programmes for several decades (Carson \& Carson 1989; Bernatzky \& Mulcahy 1992; Devey et al. 2004; Bridgwater 2005; Vivas et al. 2012; Sweeney 2013). With a much shorter history for RNC in New Zealand compared with other foliar diseases such as Dothistroma needle blight and Cyclaneusma needle cast, opportunities to measure and understand the genetic tolerance to this disease have so far been limited to a few genetic trials. The development of laboratory-based methods using a detached needle assay has offered an alternative means for screening for tolerance to RNC. Such methods allow for a more controlled infection process with higher inoculum pressure, with subsequent incubation conditions that favour the development of lesions. The ability to screen targeted populations in a controlled manner provides a tool for breeders to understand the genetics of tolerance and the relative level of genetic gain that may be expected from tolerance-focused breeding programmes.
\end{abstract}

We report on the screening of $\sim 400$ representatives of an elite radiata pine population from the Radiata Pine Breeding Company for tolerance/resistance to P. pluvialis using a detached needle assay. Our results provide evidence that breeding for tolerance to $P$. pluvialis is possible, with field-based validations underway. This will have practical application by enabling the targeted deployment of tolerant clones to disease-prone areas, and the identification of superior parents for further breeding. Breeding for tolerance/resistance will minimise dependence on chemical control strategies, an important consideration in ensuring the continued success and resilience of planted forests.

Bernatzky R, Mulcahy DL 1992. Marker-aided selection in a backcross breeding program for resistance to chestnut blight in the American chestnut. Canadian Journal of Forest Research 22: 1031-1035.

Brasier CM, Beales PA, Kirk SA, Denman S, Rose J 2005. Phytophthora kernoviae sp. nov., an invasive pathogen causing bleeding stem lesions on forest trees and foliar necrosis of ornamentals in the UK. Mycological Research 109: 853-859.

Bridgwater FKTBTMS 2005. Risk assessment with current deployment strategies for fusiform rustresistant loblolly and slash pines. Southern Journal of Applied Forestry 29: 80-87. 
Carson MJ, Carson SD 1989. Breeding for resistance in forest trees: a quantitative genetic approach. Annual Review of Phytopathlogy 27: 375-395.

Devey M, Groom K, Nolan M, Bell J, Dudzinski M, Old K, Matheson A, Moran G 2004. Detection and verification of quantitative trait loci for resistance to Dothistroma needle blight in Pinus radiata. Theoretical and Applied Genetics 108: 1056-1063.

Dick M, Williams NM, Hood IA, Bader M 2014. Pathogenicity of Phytophthora pluvialis to Pinus radiata and its relation with red needle cast disease in New Zealand. New Zealand Journal of Forestry Science 44: 6.

Durán A, Gryzenhout M, Slippers B, Ahumada R, Rotella A, Flores F, Wingfield BD, Wingfield MJ 2008. Phytophthora pinifolia sp. nov. associated with a serious needle disease of Pinus radiata in Chile. Plant Pathology 57: 715-727.

Ganley RJ, Williams NM, Rolando CA, Hood IA, Dungey HS, Beets PN, Bulman LS 2014. Management of red needle cast, caused by Phytophthora pluvialis, a new disease of radiata pine in New Zealand. New Zealand Plant Protection 67: 48-53.

Reeser PW, Sutton W, Hansen EM 2013. Phytophthora pluvialis, a new species found in mixed tanoak - Douglas-fir forests of western Oregon, U.S.A. North American Fungi 8.

Sweeney K 2013. Histological comparisons of needle tissues of four species of white pine infected by Cronartium ribicola. Unpublished thesis, Oregon State University.

Vivas M, Zas R, Solla A 2012. Screening of maritime pine (Pinus pinaster) for resistance to Fusarium circinatum, the causal agent of pitch canker disease. Forestry 85: 185-192. 


\section{SESSION 4: MITIGATION, RESILIENCE AND}

MANAGEMENT: 2

Chair: Matt Dyck, Kiwifruit Vine Health

Convener: Joy Tyson, Plant \& Food Research 


\title{
Phosphite for control of kauri dieback
}

Ian J Horner, Matthew Arnet, Ellena Carroll, Mary Horner

The New Zealand Institute for Plant and Food Research Limited, Private Bag 1401, Havelock North 4157, New Zealand

Corresponding author: ian.horner@plantandfood.co.nz

\begin{abstract}
Kauri dieback, caused by Phytophthora agathidicida, is a serious disease in northern New Zealand forests. Phosphite treatments have been tested in kauri forest trials since 2012. Five-year trials on young trees (up to $40 \mathrm{~cm}$ trunk diameter) demonstrated that $7 \%$ and $20 \%$ phosphite ( $20 \mathrm{~mL}$ injected every 20 $\mathrm{cm}$ trunk circumference) facilitated healing of Phytophthora lesions. However, phytotoxicity symptoms (leaf yellowing, canopy thinning, trunk bleeds) occurred in some phosphite-treated trees [1]. Trials were established in 2016 to investigate the use of lower phosphite concentrations (4\% injected every 20- or $40-\mathrm{cm}$ trunk circumference). Trunk spray applications are also being tested. In separate trials, injection of large trees (up to 2.5 -m trunk diameter) with very low-rate application (4\% phosphite at 40 - or 80 $\mathrm{cm}$ injector spacing) is being tested, in an attempt to determine safe but effective doses for giant trees. Early results from these trials suggest that $4 \%$ phosphite can give effective control, without obvious signs of phytotoxicity. Spreading injection points from $20 \mathrm{~cm}$ to one every $40 \mathrm{~cm}$ facilitated lesion healing in ricker trees up to $40 \mathrm{~cm}$ diameter, but was only partially effective at healing in the very large trees. Trunk spray applications of phosphite facilitated some lesion healing, but were not as effective as injection treatments.
\end{abstract}

Although there are still many unknowns about phosphite injection for kauri dieback control, the technique is starting to be deployed on a large scale in dieback-affected kauri forests in Auckland and Coromandel. A growing number of landowners (currently over 50) with kauri dieback on their properties are investigating various phosphite treatments under the Kauri Rescue ${ }^{\mathrm{TM}}$ citizen science programme.

[1] Horner IJ, Hough EG and Horner MB 2015. Forest efficacy trials on phosphite for control of kauri dieback. New Zealand Plant Protection 68: 7-12. 


\title{
Foschek: foliar applications for increasing phosphonate levels in avocados.
}

\author{
Meredith Guy, Gordon Harris, Stephen McKennie, Chris Molloy and Alan Wells
}

Lonza NZ Ltd, 15 Hudson Rd, Bell Block, New Plymouth

Corresponding author: meredith.guy@lonza.com

\begin{abstract}
Phytophthora root rot is a major disease afflicting avocado orchards in New Zealand. The causal agent is Phytophthora cinnamomi, a soil-borne fungal pathogen which can cause severe decline in tree health as well as death. In New Zealand, the main tool for controlling this disease is the application of phosphorous acid via trunk injection. Phosphorous acid is very effective in controlling this disease and others due to the highly systemic nature of the active chemical through the plant via the xylem and phloem, with direct fungal activity. It also stimulates the plants defences and the production of phytoalexins. Following application, once inside the plant, phosphorous acid forms phosphonate, which is easily translocated in the plant. The current method of trunk injection is not fool-proof, as timing is important and the process of applying by trunk injection is cumbersome. Minimum levels are also targeted to ensure control, this being $25 \mathrm{ppm}$ phosphorous acid in roots. Previously, applications of phosphorous acid on avocados for Phytophthora control in New Zealand could only be made via trunk injection, as there was no ACVM registration for other application methods. However foliar application is registered on other crops in New Zealand for the management of Phytophthora root rot. Because of the known systemic nature of phosphonate, it is generally implied that foliar applications should also be effective for increasing phosphonate levels in the roots. In other avocado growing countries, including Australia, foliar applications have been successful in increasing phosphonate levels in avocado roots to prevent Phytophthora root rot. An industry non-replicated trial carried out in Northland in 2016 using both injection and foliar application indicated that foliar applications of Foschek ${ }^{\circledR}$ should increase phosphonate levels in tree roots equivalent to that of trunk injection.
\end{abstract}

In 2019, two randomised complete block design field trials were carried out in the Bay of Plenty, on blocks which had not been previously treated with phosphorous acid, with initial root phosphorous acid levels tested at $<2 \mathrm{ppm}$ (limit of quantification). The aim was to assess the efficacy of foliar applied Foschek $^{\circledR}$ (400 g/litre phosphorous acid) and to compare this to the trunk injection method. After the autumn flush was complete, dilute foliar applications of Foschek ${ }^{\circledR}$ at $1 \mathrm{~L} / 100 \mathrm{~L}$ water was applied. One trial was carried out on young trees at Pukehina and included a single spray treatment applied on the $4^{\text {th }}$ April, a two-spray programme applied on the $4^{\text {th }}$ April and $6^{\text {th }}$ May, trunk injection applied on $4^{\text {th }}$ April, and an untreated control. A second trial was carried out at Te Puna, on larger trees. This trial concentrated on a two spray programme of Foschek ${ }^{\circledR}$ applied $5^{\text {th }}$ April and $7^{\text {th }}$ May with and without adjuvant Spreadwet 1000 at $25 \mathrm{ml} / 100 \mathrm{~L}$, compared to trunk injection applied $5^{\text {th }}$ April, and an untreated control. Root samples were tested before commencement at both sites, then on the $27^{\text {th }}$ of April prior to the second application, and again on the $7^{\text {th }}$ of June. Samples continue to be tested. Due to dry weather, individual plot root sampling did not yield high amounts of roots in the initial sampling therefore individual plots had to be bulked together per treatment to allow for sufficient sample size to conduct accurate laboratory testing.

The Pukehina trial indicated an increase up to $15 \mathrm{ppm}$ phosphorous acid in roots with a single application of Foschek ${ }^{\circledR}$ by the $7^{\text {th }}$ of June. Two applications increased levels to $25 \mathrm{ppm}$ which was a similar level to trunk injection. At Te Puna on larger trees, two applications of Foschek ${ }^{\circledR}$ increased levels of phosphorous acid to 12-16 ppm. Trunk injection did not increase levels in this trial, which indicates this method has the potential to be carried out incorrectly or not be effective at all, and root 
testing is important to check this. In the second trial, results indicated that the addition of a non-ionic adjuvant is not required with Foschek ${ }^{\circledR}$ for effective foliar applications, likely due to the formulation already containing sufficient amounts of adjuvant.

Overall, foliar applied Foschek ${ }^{\circledR}$ increased root phosphorous acid levels to similar or higher than that of trunk injection. Uptake is rapid and may allow growers to protect trees quickly and efficiently. The data gathered has led to a label claim for foliar applications of Foschek ${ }^{\circledR}$ and is now being utilised by growers. The timing of phosphorous acid applications must coincide with active root growth to ensure it is directed to the roots, as phosphorous acid will go to the parts of the tree that are growing at the time of application (sinks). This occurs in autumn, after the summer leaf flush has hardened, and again in spring following the spring leaf flush. 


\title{
Mātauranga guided biodiscovery of anti-Phytophthora compounds
}

Monica L. Gerth

School of Biological Sciences, Victoria University of Wellington, NZ.

Corresponding author: monica.gerth@vuw.ac.nz

\begin{abstract}
Our research is focused on developing new tools for controlling the spread of the pathogen, Phytophthora agathidicida, that causes kauri dieback disease. It is well established that plants are rich sources of known and potential anti-microbial compounds. In our research, we have combined a biochemical approach with mātauranga Māori in order to identify companion plants that produce antiPhytophthora compounds. Extracts of selected plants are tested in vitro against the various life cycle stages of $P$. agathidicida. Our combination of mātauranga with bioassay-directed isolations has identified multiple bioactive compounds with anti-Phytophthora activities. Overall, we believe the high hit rate in our study emphasises the value of collaborating across disciplines and knowledge systems, and particularly highlights the importance of mātauranga Māori in the response to kauri dieback.
\end{abstract}




\title{
Bio-Assay Guided Identification of Phytophthora agathidicida chemo-attractants and repellents
}

\author{
Randy Lacey, Sarah Andreassend and Monica Gerth \\ School of Biological Sciences, Victoria University of Wellington, NZ.
}

Corresponding author: monica.gerth@vuw.ac.nz

\begin{abstract}
A key part of the Phytophthora lifecycle is the production of motile zoospores. Zoospores initiate infection by swimming towards the roots of trees, encysting on the roots, and ultimately penetrating the root tissue with germ tubes. The spores navigate their environment by chemotaxis: the ability to sense chemical gradients and navigate towards favourable conditions. Our research seeks to identify the compound(s) that are produced by kauri that attract $P$. agathidicida zoospores to kauri roots. To do this we use a bio-assay guided approach in which chemotaxis assays are performed on fractionated extracts of kauri roots with subsequent identification of the chemical components via LC-MS and NMR. Thus far we have identified and characterized one unique chemoattractant compound with promising leads for two others. We have since scaled up our extraction to generate enough material for further compound identifications.

We are also exploring the role of kauri companion plants in production of both chemo-attractant and repellent signals. Because of the complexity of the forest floor surrounding kauri, it is possible that other plants in the local area contribute to the chemoattractant chemistry of the soil. Through the same process described above, we are exploring several companion plants as possible chemoattractant producers. It is also possible that some these plants produce chemorepellent compounds or general motility inhibitors. Of five plants that have been examined thus far, four of the crude extracts elicit varying degrees of chemoattractant responses with one eliciting a strong motility inhibition response. Collectively we hope this work will provide a clearer picture of the chemical environment that dictates the behaviour of $P$. agathidicida zoospores.
\end{abstract}




\title{
Why, what, and where; responding to relentless and disruptive invasive Phytophthora
}

\author{
Richard C. Cobb \\ California Polytechnic State University, Natural Resources Management and Environmental Sciences, \\ 1 Grand Ave, San Luis Obispo, CA 93407, USA
}

Corresponding author: rccobb@calpoly.edu

\begin{abstract}
We often face the most destructive Phytophthora of wildland systems with a remarkably ineffective, inadequately partial, or transitory stopgap set of options. A steady stream of newly described species, usually of cryptic origin, directly threaten wildland resources and/or horticultural commerce while many well-known Phytophthora pathogens create the same impacts and management challenges in systems that are recognized as at risk only in retrospect. Policy makers and land managers are often faced with daunting costs and impacts whether or not actions are undertaken. The deficiencies of most management options are a byproduct of the shocking epidemiological capacities of Phytophthora that capture the fascination of many pathologists while frustrating many of their efforts to ameliorate the associated diseases.

I present here a set of questions to guide policy and field-treatment decisions, the state of understanding and epidemiological realities preclude the delivery of a set of solutions. In spite of daunting Phytophthora challenges, our collective knowledge does offer meaningful actions but maximizing the benefits is contingent on critical understanding of our goals. Drawing largely on recent research on Phytophthora ramorum, I challenge the audience to confront three interconnected and familiar questions that we ignore at great peril. Why is a management action to be undertaken? Specifically, who will benefit, for how long, and at what cost. What action is proposed including understanding what time-buying treatments (eradication, inoculum reduction, etc) are worthwhile, what degree of damage triggers ecosystem restoration actions, what is the best way to develop and deploy host resistance? Lastly, where in spatiotemporal space should our efforts be applied? The most problematic Phytophthora represent difficult decisions, yet this cannot be used as an excuse to be satisfied with anything less than maximum efficacy given what is at risk.
\end{abstract}




\section{POSTERS}

Convener: Ian Horner, Plant \& Food Research

Sponsored by: Forest Owners Association / Forest Growers Commodity Levy 


\title{
First record of Phytophthora pini in New Zealand
}

\author{
K. S. J. Lewis ${ }^{1,2}$, A. Black ${ }^{1}$, L. M. Condron ${ }^{3}$, N. W. Waipara ${ }^{2}$, N. Williams ${ }^{4}$ and P. Scott ${ }^{4}$ \\ ${ }^{1}$ Bio-Protection Research Centre, P.O. Box 85084, Lincoln University, Lincoln 7647, New Zealand. \\ ${ }^{2}$ The New Zealand Institute for Plant \& Food Research Limited, Mt Albert Research Centre, 120 Mt Albert Road, Auckland \\ 1025, New Zealand \\ ${ }^{3}$ Faculty of Agriculture and Life Sciences, P.O. Box 85084, Lincoln University, Lincoln 7647, New Zealand. \\ ${ }^{4}$ Scion, Private Bag 3020, Rotorua 3046, New Zealand. \\ Corresponding author: kai.lewis@plantandfood.co.nz
}

Phytophthora gregata and Phytophthora pini were isolated by soil bioassays from kauri ecosystems within southern Waipoua Forest, New Zealand in November 2016. This is the first record of the internationally recognised pathogen $P$. pini within New Zealand. A pathogenicity assay using inoculated pine-plugs placed next to roots of potted plants in the glasshouse was conducted on kauri (Agathis australis), pine (Pinus radiata), white clover (Trifolium repens) and perennial ryegrass (Lolium perenne). Significant colonisation rates were observed for both Phytophthora isolates within pine seedlings, and to a lesser degree within kauri seedlings, compared to non-inoculated controls. Despite the recovery of both isolates from pasture soil samples, we observed little or no infection of either white clover or perennial ryegrass species, suggesting that further investigation of potential vectoring, alternative hosts, saprophytic capacity and survival of these two Phytophthora species in pasture systems may be warranted.

\section{Identifying molecular invasion patterns from the kauri dieback pathogen, Phytophthora agathidicida}

\author{
E. L. Bradley ${ }^{1,2}$, P. Panda ${ }^{3}$, R.E. Bradshaw ${ }^{4,2}$ and C. Mesarich ${ }^{1,2}$ \\ ${ }^{1}$ School of Agriculture and Environment, Massey University, Palmerston North, NZ \\ ${ }^{2}$ The Bio-Protection Research Centre, Massey University, Palmerston North, NZ \\ ${ }^{3}$ New Zealand Forest Research Institute (Scion), Rotorua, NZ \\ ${ }^{4}$ School of Fundamental Sciences, Massey University, Palmerston North, NZ \\ Correspondingemail: e.bradley@massey.ac.nz
}

Kauri, Agathis australis, is an ancient conifer species endemic to New Zealand, where it is both culturally and ecologically important. Kauri have recently been classified as a threatened species due to kauri dieback, caused by Phytophthora agathidicida. While a lot is still unknown about $P$. agathidicida, preliminary studies indicated that some kauri show levels of disease tolerance. A hallmark of plant infection by pathogens is the presence of invasion patterns. These invasion pattern molecules can be the products of plant cell damage, structural components of the pathogen, or virulence factors deployed by the pathogen to promote host colonisation. Notably, the same invasion patterns can activate the plant immune system when recognised by a corresponding plant immune receptor. This research focuses on identifying and characterising invasion patterns from $P$. agathidicida that play a role in virulence and/or are recognised by plant immune receptors. This work will increase our understanding of the interaction between pathogen and host at the molecular level, and may identify plant immune receptors responsible for invasion pattern recognition, and a subsequent defence response, which could inform a kauri breeding programme. 


\title{
Know thy enemy: plant pathogen genomics advancing disease management
}

\author{
R. L. McDougal ${ }^{1}$, P. Panda ${ }^{1}$, S. Brar ${ }^{2}$, L. Hunziker ${ }^{2}$, P.-Y. Dupont ${ }^{2}$, Y. Guo ${ }^{2}$, R.E. Bradshaw ${ }^{2}$ and \\ N.M. Williams ${ }^{1}$ \\ ${ }^{1}$ Scion (New Zealand Forest Research Institute, Ltd.), Rotorua, New Zealand \\ ${ }^{2}$ School of Fundamental Sciences, Massey University, Palmerston North, NZ \\ Corresponding author: rebecca.mcdougal@scionresearch.com
}

Genomic studies are making significant contributions to research and disease management applications in plant pathology. In addition to rapidly increasing our understanding of the molecular mechanisms underpinning pathogenesis and resistance, genomics greatly contributes to the development of novel markers for rapid pathogen detection and diagnosis and offers insights into the genetics of pathogen populations on a larger scale. The importance of understanding the diversity of pathogen populations is essential to mitigation of biosecurity risks, protecting market access and for resistance screening. Effectoromics is the study of plant pathogen effector proteins using functional genomic tools to find host resistance. It is now being used in applied research, and operationally, as a rapid highthroughput method to screen for disease resistance in many types of crops around the world. While trees present many challenges for applying these types of tools, the rewards have the potential to be hugely beneficial in productive and conservation systems worldwide.

\section{Genomic insights into a Phytophthora hybrid isolated from New Zealand soil}

\author{
W.H. Ho ${ }^{1}$, L.A. Rigano ${ }^{1}$, C. Pal ${ }^{1}$, R. McDougal ${ }^{2}$, J. Gardner ${ }^{2}$, N. Ward ${ }^{1}$, B.J.R. Alexander ${ }^{1}$ \\ ${ }^{1}$ Plant Health and Environment Laboratory, Ministry for Primary Industries, PO Box 2095, Auckland, NZ \\ ${ }^{2}$ Scion, 49 Sala Street, Rotorua, New Zealand \\ Corresponding author: wellcome.ho@mpi.govt.nz
}

Phytophthora plant pathogens are causing significant damage on primary production and natural ecosystems worldwide. The emergence of Phytophthora hybrid species is leading to expanded host ranges and new virulent strains. In 2018, we isolated a Phytophthora isolate from a garden soil sample in Rotorua. Initial taxonomic characterisation of the isolate using a set of marker genes suggested it could be a hybrid species. To further characterise this potential hybrid, the whole genome was sequenced using Illumina and PacBio technologies, assembled (95.3\% completeness) and annotated. Pathogenicity-related motifs, such as RxLR effectors, were found. Numerous single-nucleotide polymorphisms were found in multiple gene loci, including nuclear and mitochondrial genes that are commonly used as marker genes for taxonomic identification within the genus. We developed a differential read mapping approach that can separate sequences from each parent. Using this strategy we were able to identify the strain as the previously described $P$. serendipita, a hybrid of $P$. hedraiandra and $P$. cactorum. Through re-examination of archived sequences, a group of $P$. cactorum isolates from puka soil and persimmon fruits were re-identified as $P$. hedraiandra. This indicates that $P$. hedraiandra is present in New Zealand. 


\title{
Analysis of Host-Pathogen Interactions by Liquid Chromatography Mass Spectroscopy (LC-MS)
}

\author{
S. J. Hill, I. Isak, and L. G. Raymond \\ Scion, 49 Sala St, Rotorua 3046, New Zealand \\ Corresponding author: Stefan.Hill@scionresearch.com
}

LC-MS is an analytical technique that measures the unique molecular weight of compounds, that can then be used to identify individual chemicals. In order to identify infection-induced up- or downregulated metabolites, a study was carried out on Pinus radiata plants inoculated within two fogging chambers; one with non-infected control plants and another with Phytophthora pluvialis-inoculated plants. Pine needles were sampled before infection and then 7 and 42 days after infection and analysed by LC-MS to determine chemical compounds produced in response to infection. The analysis indicated only minor differences in the chemical profile of needles between 0 days and 7 days post-inoculation. At 42 days post-inoculation the infected specimens showed significant differences compared to the corresponding controls, and to the specimens taken from the earlier time periods. Interestingly, two control specimens exhibited behaviours similar to the inoculated specimens, warranting further investigation. Eleven plant defence related compounds were identified in inoculated specimens which showed direct response to infection 42 days post-inoculation. These identified compounds are potential markers for infection which, with their levels of production and genetic regulation, are potential chemical markers for resistance.

\section{Using NMR to study host-pathogen interactions between kauri callus tissues and Phytophthora species}

\author{
L. G. Raymond, S. J. Hill and N. M. Williams.
}

Scion, 49 Sala St, Rotorua 3046, New Zealand

Corresponding author: Laura.Raymond@scionresearch.com

Kauri (Agathis australis), one of New Zealand's most iconic indigenous tree species is currently under serious threat from kauri dieback, a deadly disease caused by the pathogen Phytophthora agathidicida. To aid in the understanding of the mode of infection of Phytophthora, we have implemented a metabolomics approach based on nuclear magnetic resonance (NMR) and liquid chromatography-mass spectrometry (LC-MS) to understand chemical markers associated with the various infection stages. Complications can arise in analysis when dealing with real world trees that have not only Phytophthora, but a host of unknown other biotic and abiotic stressors impacting on the metabolome. To overcome this challenge and single out chemical markers for Phytophthora infection (either from the host or Phytophthora), plant callus tissue was cultured as model system for studying host-pathogen interactions. Kauri callus tissue was challenged with three species of Phytophthora known to infect kauri (P. agathidicida, P. cinnamomi and P. multivora) and ${ }^{1} \mathrm{H}$ NMR spectroscopy of aqueous extracted secondary metabolites was used to screen the validity of this approach to understand the infection process. Preliminary ${ }^{1} \mathrm{H}$ NMR analysis indicated that the un-inoculated controls and Phytophthora infected callus tissues have statistically distinct chemical profiles and these differences correlate with the level of Phytophthora infection. 


\title{
Characterisation of RXLR effectors from the kauri pathogen Phytophthora agathidicida
}

Y. Guo ${ }^{1}$, P.Y. Dupont ${ }^{1,2}$, C.H. Mesarich $^{3}$, P. Panda ${ }^{4}$, N.M. Williams ${ }^{4}$, R.L. McDougal ${ }^{4}$, and R.E. Bradshaw $^{1}$

\author{
${ }^{I}$ BioProtection Research Centre, Fundamental Sciences, Massey University, Palmerston North, NZ, \\ ${ }^{2}$ Institute of Environmental Science and Research, Christchurch, NZ, \\ ${ }^{3}$ BioProtection Research Centre, Agriculture and Environment, Massey University, Palmerston North, NZ, \\ ${ }^{4}$ Scion, Rotorua, $N Z$. \\ Corresponding author:y.guo.1@massey.ac.nz
}

Kauri (Agathis australis), an iconic native tree species of NZ, is threatened by dieback disease, caused by Phytophthora agathidicida. A preliminary screen at Scion suggests that natural tolerance to dieback is present in kauri populations. However, little is known about how P. agathidicida interacts with kauri at the molecular level. In this study pathogen effector proteins of the RXLR class, which are known to be important in other Phytophthora pathosystems, were identified and characterised in P. agathidicida. Altogether, 75 RXLRs were analysed using an Agrobacterium-based assay in Nicotiana sp. Eight RXLRs triggered cell death, suggesting recognition by cognate immune receptors in Nicotiana. Of these, PaRXLR24, an orthologue of the Phytophthora sojae RXLR Avh238, was studied further and amino acids required for cell death-inducing activity were identified. Another effector, PaRXLR40, was found to suppress PaRXLR24-triggered cell death. Both PaRXLR24 and PaRXLR40 are highly expressed in planta. In future, RXLRs will be screened in kauri to identify host targets/immune receptors. This will improve our understanding of how $P$. agathidicida and kauri interact at the molecular level and will ultimately help inform dieback resistance breeding programmes.

\section{Discovery and characterisation of viral and viral-like sequences associated with the genomes of New Zealand Phytophthora species}

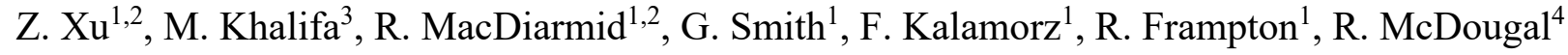 \\ ${ }^{I}$ Plant and Food Research, Auckland \& Lincoln, NZ \\ ${ }^{2}$ University of Auckland, $N Z$ \\ ${ }^{3}$ Damietta University, Damietta, Egypt \\ ${ }^{4}$ Scion, Rotorua, $N Z$ \\ Corresponding author:Zhi.Xu@plantandfood.co.nz
}

The Phytophthora genus contains species that are pathogenic to a range of plants. Some Phytophthora species in New Zealand are associated with diseases, yet are poorly characterised, with limited understanding of their ecological niche, pathogenicity determinants or management options. Recently, reports have described un-encapsidated viruses from Phytophthora infestans, Phytophthora taxon douglasfir and Phytophthora ramorum. This study aims to investigate and characterise viruses and virallike sequences associated with Phytophthora isolates in New Zealand, and to assess the effect of these viruses on their host's biology and pathogenicity. Preliminary data suggest that viruses are present in Phytophthora pluvialis, a pathogen of Pinus radiata. This study will characterise these potential viruses in P. pluvialis, then investigate viruses associated with other Phytophthora species. Since Gemini-like virus sequences have been found in Phytophthora infestans and Phytophthora sojae, we will look for Gemini-like and other viral-like sequences within Phytophthora genomes and mitochondrial assemblies. We also aim to develop diagnostic tools to detect viruses associated with Phytophthora species, and to determine the potential for virus transmission between Phytophthora species. This understanding of viruses may lead to alternative options to control pathogenic Phytophthora in New Zealand. 


\title{
Effects of plant nutrient amendments on infection and disease of kauri (Agathis australis) caused by Phytophthora agathidicida
}

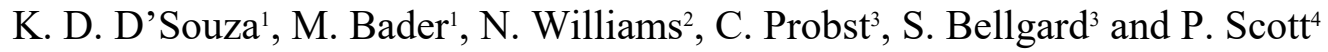 \\ ${ }^{1}$ Auckland University of Technology, Auckland, New Zealand \\ ${ }^{2}$ Scion, Rotorua, New Zealand \\ ${ }^{3}$ Manaaki Whenua - Landcare Research, New Zealand \\ ${ }^{4}$ Plant \& Food Research, Te Puke, New Zealand \\ Corresponding author: kim_d@hotmail.co.nz
}

New Zealand kauri (Agathis australis) are culturally, socially and ecologically significant within northern New Zealand podocarp forest ecosystems. Phytophthora agathidicida is an aggressive and deadly pathogen, capable of killing kauri across its ecological range, with high-level impacts being observed. This has instigated a cultural intervention "rahui" aimed at controlling public access to the infected track network. The control and management of $P$. agathidicida in forest ecosystems is challenging with no definitive cure for infected trees, and strong public opinion about the correct way forward for the long-term management of kauri. This research investigates how the addition of micronutrient treatments, including manganese and zinc, iron or a mixed treatment could act to reduce dieback disease expression. Kauri seedlings were inoculated with $P$. agathidicida, followed by micronutrient treatments being applied by foliar spray. Fortnightly assessments including health rating, plant height and chlorophyll fluorescence were conducted to assess physiological health, for a total of 12 weeks. These findings could potentially add to the suite of tools available for the management and conservation of kauri, in the presence of kauri dieback.

\section{Inoculating Agathis australis with fungal endophytes to test the viability of a potential biological control agent for Phytophthora agathidicida}

\author{
K.A. Bradford, M. Padamsee, N.M. Williams, J. Krajňáková \\ Scion Research, 49 Sala Street, Whakarewarewa, Rotorua, 3010 \\ Corresponding author: Ki-Taurangi.Bradford@scionresearch.com
}

Phytophthora agathidicida has had a detrimental effect on the Agathis australis (kauri) population in New Zealand. P. agathidicida is an oomycete pathogen found in the roots of kauri trees. Attempts to eradicate the disease have been unsuccessful. Some fungal endophytes have positive interactions with host plants by providing protective secondary metabolites as well as competing for nutrients against pathogens. My hypothesis is that certain fungal endophytes will have a beneficial relationship with $A$. australis and outcompete $P$. agathidicida for nutrients, thus creating a healthy living environment for the kauri. Two fungal endophyte strains originally isolated from kauri roots will be assessed for their viability as biological control agents. Experiments will test different methods to inoculate sterile tissueculture kauri and the movement of the endophytes in different types of kauri tissue and the effect they have on growth will be monitored. Inoculated tissue culture plants will be grown in sterile soil to observe a more natural interaction between endophytes and kauri. If the endophytes are successful in colonising A. australis tissue without causing negative effects, it may be possible to co-culture $P$. agathidicida with inoculated $A$. australis to observe whether the endophytes will provide protection against the disease. 


\title{
Antimicrobial resistance and sensitivity in Phytophthora agathidicida
}

\author{
K.J. Daley, M. L. Gerth, W.M. Patrick \\ School of Biological Sciences, Victoria University of Wellington, NZ \\ Corresponding author:daleykait@myvuw.ac.nz
}

Members of the genus Phytophthora are some of the most destructive plant pathogens internationally. In New Zealand, the species $P$. agathidicida is the cause of kauri dieback. The number of kauri showing signs of infection have increased to above $20 \%$ in the Waitakere ranges. Agrichemical and other hygiene control approaches are failing to prevent the spread of the pathogen. The only agrichemical that is being trialled as a control mechanism is phosphite. The procedure is direct injection into the trunks of affected kauri. The aim of this research is to quantity the toxicity of phosphite towards P. agathidicida and to assess the likelihood of phosphite resistance emerging. The effective inhibitory concentration of pure phosphite has been determined under laboratory conditions (on amended potato dextrose agar), and compared to the effective concentrations of commercially formulated phosphite preparations. The effect of the surfactants and adjuvants in these commercial preparations has also been assessed. The probability of phosphite resistance developing in P. agathidicida is also being investigated. Phosphiteresistant isolates are being evolved via a serial passaging protocol in a contained laboratory environment. These experiments are ongoing, and up-to-date results will be presented.

\section{Mātauranga and microbiology: a new type of education}

\author{
A. Sucsy and M.L. Gerth \\ School of Biological Sciences, Victoria University of Wellington, NZ \\ Corresponding author: monica.gerth@vuw.ac.nz
}

Te kura o te kauri is a collaborative outreach program focused around kauri dieback and kauri forest health. It aims to get children excited about microbial science and emphasise the concepts of kaitiakitanga for the forest, and good forest hygiene. By combining research from leading scientists at Victoria, Auckland and Lincoln universities with mātauranga Māori, the project provides a holistic framework in which to learn, teach, and interact with the environment. Researchers and artists are working together to create a new sort of educational program. For example; a virtual reality world brings a child from towering above a kauri forest, to diving down into the soil to see the roots and the microbe that causes kauri dieback. The project will culminate in a four week tour of schools in Northland and Northern Auckland using the repurposed "Lab In A Box" from the Otago museum. Everywhere it travels, local engagement leaders will be present to deliver the content to local schools and provide their place specific korero, their own personal stories and connection to kauri. 


\title{
Destroying the Plant Destroyer: Biodiscovery of new anti-microbials to prevent kauri dieback.
}

\author{
M.J. Fairhurst and M.L. Gerth \\ School of Biological Sciences, Victoria University of Wellington. \\ Corresponding author: monica.gerth@vuw.ac.nz
}

There is an urgent need for novel anti-microbials that affect the oospores to control the kauri dieback pathogen Phytophthora agathidicida. However, Phytophthora has a complex lifecycle that has made control difficult. The three key stages of the Phytophthora lifecycle are oospores (survival spores), zoospores (motile, infectious spores), and mycelial growth (host colonisation). Oospores are the most persistent (and resistant) stage of the lifecycle. A limited number of anti-microbials are available that are effective against zoospores and/or mycelial growth, however, most of these are not effective against oospores. Our project is focused on developing new anti-microbials effective against all of the Phytophthora lifecycle stages. Here, we will present our research on oospore deactivation. We have developed improved protocols for oospore production and viability testing. We are also testing a variety of compounds and extracts in order to test their effects on oospore viability and germination. Combined, we hope this research will facilitate the development of effective tools to slow the spread of kauri dieback disease.

\section{Foliar phosphite application controls Phytophthora cinnamomi in six ecologically significant New Zealand plant species}

\author{
Peter Scott ${ }^{1}$, Nari Williams², Martin Bader ${ }^{3}$ \\ ${ }^{1}$ The New Zealand Institute for Plant and Food Research Limited, 412 No 1 Rd, Te Puke \\ ${ }^{2}$ Scion, New Zealand Forest Research Ltd., 49 Sala Street, Rotorua 3010 \\ ${ }^{3}$ Auckland University of Technology, 31-33 Symonds Street, Auckland 1142. \\ Corresponding email: peter.scott@plantandfood.co.nz
}

Background: Phosphite is one of the only current means of chemical control of Phytophthora diseases in forest systems and is a valuable tool to help reduce the rate of spread new incursions. Low volume foliar phosphite application has been shown to have minimum eco-physiological and necrotic impacts on a variety of conifer and broadleaf species native to New Zealand.

Method: The effectiveness of phosphite to control disease caused by Phytophthora cinnamomi was tested in six New Zealand native species, including kauri (Agathis australis), tawa (Beilschmiedia tawa), rimu (Dacrydium cupressinum), pōhutukawa (Metrosideros excels), tōtara (Podocarpus totara) and akeake (Dodonaea viscosa). Potted seedlings were sprayed with phosphite at rates of 0 and $12 \mathrm{~kg}$ a.i. ha-1. One year after phosphite treatment, plants were stem wound inoculated with P. cinnamomi.

Results: $P$. cinnamomi caused significant visible and asymptomatic lesion extension; however, phosphite application significantly controlled lesions in all species.

Conclusions: Phosphite was effective at managing P. cinnamomi disease in native species, one year after treatment application, and may have long term efficacy. 


\title{
Kauri Rescue ${ }^{\mathrm{TM}}$ : A citizen science programme evaluating kauri dieback controls
}

Ian Horner ${ }^{1}$, Mels Barton ${ }^{2}$, Lee Hill ${ }^{3}$, Linley Jesson ${ }^{1}$, Ngaire Kingsbury ${ }^{4}$, Marie McEntee ${ }^{5}$, Nick Waipara $^{6}$, Waitangi Wood ${ }^{7}$

${ }^{1}$ The New Zealand Institute for Plant and Food Research Limited, Private Bag 1401, Havelock North 4157

${ }^{2}$ Subliminal Ltd, PO Box 60-203 Titirangi 0642

${ }^{3}$ Biosense Ltd, 128 Symonds Street, Auckland

${ }^{4}$ PO Box 60-535 Titirangi 0642

${ }^{5}$ Aranovus Ltd., PO Box 24-522, Royal Oak 1345

${ }^{6}$ The New Zealand Institute for Plant and Food Research Limited, 120 Mt Albert Road, Auckland 1025

${ }^{7}$ PO Box 178 Kaeo, Northland 0479

Corresponding author: ian.horner@plantandfood.co.nz

Kauri dieback, caused by Phytophthora agathidicida, causes decline and death of kauri trees in northern New Zealand. Many affected trees are on private land, and landowners are desperate for treatments to save their trees. Kauri Rescue ${ }^{\mathrm{TM}}$ is a citizen science programme aimed at providing experimental control tools to landowners, whilst helping with the refinement of those tools. Participants with infected trees are provided with the equipment required for treatment of their trees, and asked to collect tree health data before treatment and 6-monthly thereafter. Participants are provided with manuals and videos on treatment application and data collection methods, with suggestions of treatment options and application rates. The systems developed can be used for monitoring any type of kauri dieback treatment, including mātauranga Māori methods, although to date almost all participants have selected various rates of phosphite as their main treatment. A community of volunteers is available to help participants with large properties or many trees to treat.

\section{Evidence of phosphite resistance in Phytophthora species with intensive use in nurseries and horticulture}

\author{
S.R. Hunter ${ }^{1}$, P.M. Scott ${ }^{2}$, N.M. Williams ${ }^{3}$, and R.L. McDougal ${ }^{3}$ \\ ${ }^{1}$ Plant \& Food Research, Auckland \\ ${ }^{2}$ Plant \& Food Research, Te Puke \\ ${ }^{3}$ Forest Protection, Scion, Rotorua \\ Corresponding author: Shannon.Hunter@plantandfood.co.nz
}

Phosphite is used to manage diseases caused by Phytophthora species, which include a large number of the most economically damaging plant pathogens worldwide. Phosphite controls the growth of Phytophthora species in planta without killing it; as a result, isolates can develop tolerance to phosphite after prolonged exposure. Using radial growth tests, we assessed the phosphite sensitivity of $P$. cinnamomi isolates from NZ avocado orchards and eleven Phytophthora species isolated from nurseries and restoration sites in California, USA. No P. cinnamomi isolates were resistant to control with phosphite. However, the isolates identified as having increased tolerance were from orchards with prolonged phosphite exposure. Phytophthora ramorum, P. lateralis, P. crassamura and P. cambivora showed intraspecific variability in phosphite sensitivity, with at least one isolate showing significantly higher tolerance than the other isolates. Within the three $P$. ramorum evolutionarily divergent lineages tested, NA1 was the most susceptible to phosphite, the NA1 and EU1 lineages showed intralineage variability and all NA2 isolates were relatively tolerant. This finding is relevant because NA1 is dominant in the wild and can be controlled using phosphite, while the EU1 lineage has recently been identified in the wild and is phosphite-tolerant, making the treatment approach potentially less effective. 
NOTES 
NOTES 



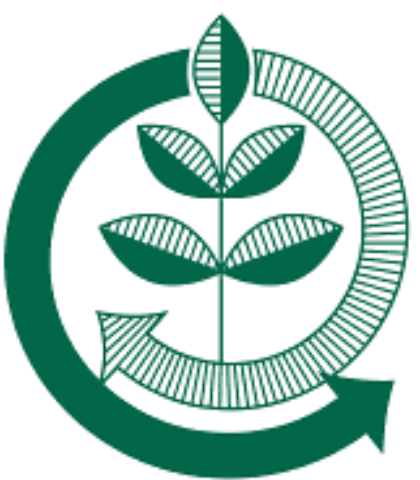

(C) New Zealand Plant Protection Society (Incorporated)

ISBN 978-0-473-49002-7 